\title{
Silver nanoparticles embedded in zeolite membranes: release of silver ions and mechanism of antibacterial action
}

This article was published in the following Dove Press journal:

International Journal of Nanomedicine

5 September 201 I

Number of times this article has been viewed

\author{
Amber Nagy' \\ Alistair Harrison ${ }^{2}$ \\ Supriya Sabbani ${ }^{3}$ \\ Robert S Munson, Jr2 \\ Prabir K Dutta ${ }^{3}$ \\ W James Waldman' \\ 'Department of Pathology, The Ohio \\ State University; ${ }^{2}$ Center for Microbial \\ Pathogenesis, Research Institute \\ at Nationwide Children's Hospital, \\ ${ }^{3}$ Department of Chemistry, The Ohio \\ State University, Columbus, $\mathrm{OH}$, USA
}

Correspondence: Prabir K Dutta 100 West 18th Avenue, Columbus, $\mathrm{OH} 43210-1173$, USA

$\mathrm{Tel}+\mathrm{I} 6142924532$

Fax + I 6146885402

Email dutta@chemistry.ohio-state.edu
Background: The focus of this study is on the antibacterial properties of silver nanoparticles embedded within a zeolite membrane (AgNP-ZM).

Methods and Results: These membranes were effective in killing Escherichia coli and were bacteriostatic against methicillin-resistant Staphylococcus aureus. E. coli suspended in Luria Bertani (LB) broth and isolated from physical contact with the membrane were also killed. Elemental analysis indicated slow release of $\mathrm{Ag}^{+}$from the AgNP-ZM into the LB broth. The E. coli killing efficiency of AgNP-ZM was found to decrease with repeated use, and this was correlated with decreased release of silver ions with each use of the support. Gene expression microarrays revealed upregulation of several antioxidant genes as well as genes coding for metal transport, metal reduction, and ATPase pumps in response to silver ions released from AgNP-ZM. Gene expression of iron transporters was reduced, and increased expression of ferrochelatase was observed. In addition, upregulation of multiple antibiotic resistance genes was demonstrated. The expression levels of multicopper oxidase, glutaredoxin, and thioredoxin decreased with each support use, reflecting the lower amounts of $\mathrm{Ag}^{+}$released from the membrane. The antibacterial mechanism of AgNP-ZM is proposed to be related to the exhaustion of antioxidant capacity.

Conclusion: These results indicate that AgNP-ZM provide a novel matrix for gradual release of $\mathrm{Ag}^{+}$.

Keywords: silver nanoparticles, zeolite, antibacterial agent, oxidative stress

\section{Introduction}

Given that we are in an era where antibiotic resistance is a growing concern, there is a renewed interest in developing products containing silver for use as antimicrobials. For thousands of years, silver has been used for food and beverage preservation, and in medicines. ${ }^{1}$ The use of silver as an antibacterial agent declined with the discovery of antibiotics, but the evolution of antibiotic-resistant pathogens has brought a revival in silver-based applications. Silver is now an additive in consumer products including bandages, socks, shirts, water filters, antiperspirants, combs, paints, and washing machines. $^{2}$

The antibacterial mechanism of silver nanoparticles (AgNP) and $\mathrm{Ag}^{+}$has been explored extensively. Baker et $\mathrm{al}^{3}$ found that complete bacterial cell death could be achieved at $8 \mu \mathrm{g} / \mathrm{cm}^{2} \mathrm{AgNP}$ and that smaller particles were more efficient antibacterials. Others have supported this finding, and found that the amount of chemisorbed $\mathrm{Ag}^{+}$ and aggregation status of AgNP influences antibacterial efficacy. ${ }^{4}$ The formation of reactive oxygen species has been implicated in bacterial toxicity, ${ }^{5}$ and these are 
thought to damage DNA and proteins, as well as perturb cell membrane integrity. ${ }^{6}$

However, there is growing concern surrounding the increasing use of AgNP and their impact of the environment. The spread of AgNP into wastewater is an environmental concern, in that researchers have found that the numbers of nitrifying bacteria found in sludge are reduced when exposed to large quantities of AgNP, ${ }^{7}$ which has severe implications on waste water treatment.

This motivated us to develop a method to immobilize AgNP into lithographically patterned zeolite membranes, and we have already reported that such membranes are effective in killing Escherichia coli upon contact. ${ }^{8}$ Other research in this area has focused on $\mathrm{Ag}^{+}$-zeolite powders as antibacterial agents. $\mathrm{Ag}^{+}$ions are ion-exchanged out of the zeolite powder into media and are sufficient to cause bacterial cell death in both E coli and Staphylococcus aureus. ${ }^{9,10}$ In the case of $\mathrm{Ag}^{+}$-zeolite, the release of $\mathrm{Ag}^{+}$into solution is primarily determined by the ionic strength of the medium, because this is an ion-exchange process and is media-dependent. Recently, there has also been a report of AgNP in zeolite powders and their activity towards Gram-positive and Gramnegative bacteria. ${ }^{11}$

In this study, we investigated the antibacterial capacity of AgNP embedded in zeolite membranes (AgNP-ZM) and found that their bactericidal properties stem from the gradual release of $\mathrm{Ag}^{+}$into the media. From a materials perspective, zeolite membranes are more attractive as supports than powders, since macroscopic membranes can be grown on ceramics, metals, and polymeric and cellulose supports, ${ }^{12}$ thus allowing for diverse applications, including use in the hospital setting. The mechanism of $E$. coli death was investigated using viability assays, gene expression arrays, and quantitative reverse transcriptase polymerase chain reaction (PCR). The biological studies suggest that exhaustion of antioxidant capacity is related to antibacterial function.

\section{Materials and methods Materials}

Silver nitrate (99\%), potassium nitrate, trypan blue, polyethylene glycol, Ludox SM-30, poly(methyl methacrylate), and hydrazine were purchased from Sigma Aldrich (St. Louis, MO). PEG-600 (Fluka, Buchs, Switzerland), Darvan (RT Vanderbilt Co Inc, Norwalk, CT), aluminum hydroxide (Alfa Aesar Ward Hill, MA, 80.5\%), sodium hydroxide (Mallinckrodt Hazelwood, MO, 98.8\%), 25 wt\% tetramethyl ammonium hydroxide aqueous solution (Sachem, Austin, TX), AKP30 high-purity alumina powder (Sumitomo Chemical Co
Ltd, Tokyo, Japan), with an average particle size of $300 \mathrm{~nm}$, silastic T-2 polydimethylsiloxane (Dow Corning, Midland, MI), 200 proof ethyl alcohol (Pharmco, Brookfiled, CT), and 1-octanol (Puriss, Fluka, Buchs, Switzerland) were also purchased and used without further purification. Luria Bertani (LB) broth powder agar, brain heart-infusion broth, $100 \mathrm{~mm}$ sterile Petri dishes, and chloroform were obtained from Fisher Scientific (Pittsburgh, USA) and $0.4 \mu \mathrm{m}$ pore transwell plates and six-well plates were obtained from Corning (Lowell, MA). Qiagen (Valencia, CA) supplied the Puregene DNA purification kit, the RNeasy RNA isolation kit, DNase, and QuantiTect SYBR Green reverse transcriptase PCR kit. Primers were purchased from Integrated DNA Technologies (San Diego, CA). The E. coli strain, XL-1 blue, which was derived from the K-12 strain, was a kind gift from Dr Joanne Trgovcich (Department of Surgery, The Ohio State University Medical Center). Bioanalyzer Lab-On-A-Chip Agilent 6000 Series II chips and E. Coli 8x15K Microarrays were purchased from Agilent (Santa Clara, CA).

\section{Synthesis of AgNP-ZM}

Macroporous alumina oxide supports were used as the substrate for zeolite membrane growth, and their preparation is described in detail in earlier studies. ${ }^{13}$ Briefly, nanometer-sized zeolites are deposited on the alumina support and grown into a continuous membrane by hydrothermal synthesis. The zeolite membranes were then ionexchanged with $0.005 \mathrm{M} \mathrm{AgNO}_{3}$ solution, washed, and then reduced by hydrazine, as described earlier. ${ }^{8}$ After washing, the AgNP-ZM were extensively ion-exchanged with $1 \mathrm{M}$ $\mathrm{NaCl}$ to remove unreacted silver ions from the zeolite. A schematic of AgNP-ZM fabrication is provided in Supplemental Figure 1.

\section{Chemical characterization of AgNP-ZM}

Supernatants were collected from AgNP-ZM suspended in LB broth for various times and used for elemental analysis. Similar experiments were done with AgNP-ZM that were repeatedly exposed to LB broth. Silver content was measured using inductively coupled plasma optical emission spectroscopy at Galbraith Laboratories, Knoxville, TN.

\section{Biological characterization}

Cultures of XL-1 blue E. coli were incubated with the AgNP-ZM or zeolite membrane controls and assessed for viability using traditional colony counts. LB broth solution was prepared using a concentration of $25 \mathrm{~g} / \mathrm{L}$ of LB. LB agar plates were prepared with $1.5 \%$ agar. Individual 
clones were inoculated in $3 \mathrm{~mL}$ of LB broth and shaken at $225 \mathrm{rpm}$ overnight at $37^{\circ} \mathrm{C}$. Prior to exposing bacteria to the zeolite membranes, bacterial cultures were adjusted to obtain an initial optical density between 0.2 and 0.8 , with viable colony counts ranging between about $1 \times 10^{5}$ and $1 \times 10^{8}$ colony-forming units $(\mathrm{cfu}) / \mathrm{mL}$. For the initial viability experiment, one zeolite membrane and one freshly prepared AgNP-ZM were tested three times. Membranes were placed into six-well tissue culture plates and $5 \mathrm{~mL}$ (approximately $1 \times 10^{6}$ cells $/ \mathrm{mL}$ ) of bacterial suspension was added to each well. Experimental plates were then incubated at $37^{\circ} \mathrm{C}$ and continuously shaken. For each experiment, samples were removed at $0,30,60,120$, and 180 minutes, where $100 \mu \mathrm{L}$ was taken from wells containing zeolite controls or AgNP-ZM and added to a tube containing $0.9 \mathrm{~mL}$ of LB broth. Samples were further diluted in LB broth by 10 -fold six more times. To obtain colony counts, $100 \mu \mathrm{L}$ of samples were plated from each dilution. LB plates were incubated at $37^{\circ} \mathrm{C}$ overnight and cfu were counted to determine bacteria viability. Optical densities of culture supernatants were measured after exposure to two separate AgNP-ZM for 60, 120, or 180 minutes using a Shimadzu spectrophotometer at an absorbance wavelength of $600 \mathrm{~nm}$.

We also tested the preliminary antibacterial activity of AgNP-ZM against a methicillin-resistant strain of $S$. aureus (MRSA, a kind gift from Dr Vijay Pancholi, Department of Pathology, The Ohio State University). Here, a clone of MRSA was grown overnight in brain-heart infusion broth. A fresh stock was inoculated into brain heart-infusion broth from the overnight culture and grown at $37^{\circ} \mathrm{C}$ under continuous shaking until the optical density reached 0.3 . Bacterial cultures $(5 \mathrm{~mL}$ in brain heart-infusion broth, about $5 \times 10^{7}$ cell $/ \mathrm{mL}$ ) were then exposed to zeolite membranes or AgNP-ZM for up to 180 minutes. Samples were taken and serially diluted as described above. Samples from each dilution $(100 \mu \mathrm{L})$ were streaked onto brain heart-infusion agar and incubated for 24 hours at $37^{\circ} \mathrm{C}$ prior to counting. Zeolite membranes were reused after decontamination by steam autoclave or with $70 \%$ ethanol for 20 minutes prior to air drying.

To determine if the antibacterial action of AgNP-ZM is contact-dependent, two approaches were taken. We first exposed two AgNP-ZM and one zeolite membrane control to $5 \mathrm{~mL}$ of LB broth for three hours. E. coli (at a concentration of approximately $1 \times 10^{5}$ cells $/ \mathrm{mL}$ in $5 \mathrm{~mL}$ of LB broth) was pelleted by centrifugation $(3250 \times \mathrm{g})$ for 15 minutes The supernatants were discarded and the bacteria were resuspended in supernatants that had been exposed to the membranes. Samples were incubated at $37^{\circ} \mathrm{C}$ and $100 \mu \mathrm{L}$ samples were taken at 30,60, and 120 minutes. Colony counts were performed in the same manner as stated above, where a series of 10 -fold dilutions were prepared, and $100 \mu \mathrm{L}$ from each dilution was plated on LB agar. Plates were incubated for 24 hours at $37^{\circ} \mathrm{C}$ prior to counting.

To test further whether the antibacterial action of AgNP-ZM is contact-dependent, two AgNP-ZM and one zeolite membrane control were each placed in separate wells of six-well transwell plates with a membrane pore size of $0.4 \mu \mathrm{m}$. The membranes did not touch the bottom surface of the transwells. E. coli (approximately $1 \times 10^{5}$ cells $/ \mathrm{mL}$ in $5 \mathrm{~mL}$ LB broth) was applied to the apical chamber of the transwell plates. Plates were continuously shaken and incubated at $37^{\circ} \mathrm{C}$. From the apical and basal chambers, $100 \mu \mathrm{L}$ samples were taken after 30, 60, and 120 minutes, diluted using the serial dilution scheme described above, plated, and incubated overnight at $37^{\circ} \mathrm{C}$.

The efficacy of AgNP-ZM was tested by exposing the same AgNP-ZM to approximately $1 \times 10^{6}$ cells $/ \mathrm{mL}$ of $E$. coli in $5 \mathrm{~mL}$ of LB broth a total of six times. LB broth samples $(100 \mu \mathrm{L})$ were collected at 30, 60, and 120 minutes during each of the six experimental exposures. Colony counts were performed in the same manner stated earlier in the Materials and Methods section, where a series of 10-fold dilutions were prepared from the samples, and $100 \mu \mathrm{L}$ from each dilution was plated on LB agar. Plates were incubated for 24 hours at $37^{\circ} \mathrm{C}$ prior to counting. In between each use, the AgNP-ZM were sterilized by steam autoclave, much like surgical instruments found in a hospital setting.

\section{DNA and RNA extraction}

E. coli genomic DNA was isolated using a Puregene DNA purification kit according to the manufacturer's instructions. Bacterial RNA was extracted using standard procedures from $E$. coli exposed to zeolite membranes or exposed to AgNP-ZM for 30-45 minutes (see Supplemental Methods). The quality of RNA was examined using an Agilent 2100 Bioanalyzer Lab-On-A-Chip Agilent 6000 Series II chip. RNA samples were checked for DNA contamination by running PCR using samples with primers with or without reverse transcriptase. The presence of PCR products was determined by gel electrophoresis using 1\% agarose gel.

\section{Gene expression microarrays}

Four individual zeolite supports containing AgNPs and four zeolite support controls were exposed to approximately $1 \times 10^{8} \mathrm{cfu} / \mathrm{mL}$ of bacteria for 30 minutes prior to RNA 
isolation, and bacterial viability was determined via colony counts (Supplemental Figure 2). RNA samples were stored at $-80^{\circ} \mathrm{C}$ until processing. Sample labeling and hybridizations were performed by the Nationwide Children's Hospital's Biomedical Genomics Facility (http://genomics.nchresearch. org/index.html). The RNA was of high quality and all samples passed the standard quality control cutoff. Sample labeling and hybridization was performed according to the manufacturer's protocols. Samples were hybridized to the $E$. coli $8 \times 15 \mathrm{~K}$ Microarray (AMADID 020097). Parameters regarding gene array methodology, quality control, and statistical analyses are included in the Supplemental Materials section.

\section{Quantitative reverse transcriptase PCR}

E. coli at a concentration of $1 \times 10^{8} \mathrm{cfu} / \mathrm{mL}$ were exposed to zeolite membranes alone or containing AgNPs for 45 minutes prior to RNA isolation. Quantitative reverse transcriptase PCR analyses were completed using a Quantitect SYBR Green reverse transcriptase PCR kit under the following conditions. Master mixes were prepared using $12.5 \mu \mathrm{L}$ $2 \times$ QuantiTect SYBR Green Master Mix, $0.25 \mu \mathrm{L}$ QuantiTect reverse transcriptase mix, and $10.25 \mu \mathrm{L}$ RNase-free water per reaction. Forward and reverse primers were added using $0.5 \mu \mathrm{L}$ from $25 \mu \mathrm{M}$ stocks, and primer sequences are listed in Supplemental Table 1. Master mixes were aliquoted into 96-well plates ( $24 \mu \mathrm{L} /$ well) along with $1 \mu \mathrm{L}$ of RNA at a concentration of $1 \mathrm{ng} /$ reaction. Reactions were cycled under the following conditions. Reverse transcription was performed for 30 minutes at $50^{\circ} \mathrm{C}$. PCR activation was performed at $95^{\circ} \mathrm{C}$ for 15 minutes. Denaturation occurred at $94^{\circ} \mathrm{C}$ for 15 seconds, annealing occurred for 30 seconds at $58^{\circ} \mathrm{C}$ and extension occurred at $72^{\circ} \mathrm{C}$ for one minute. Cycling conditions were repeated 35 times. The ABI Prism 7500 sequence detection system was used to quantify gene expression using a gene-specific standard curve generated with bacterial DNA.

\section{Statistical analysis}

Significant differences in E. coli viability after incubation with AgNP-ZM and negative controls were determined by one-way analysis of variance using SigmaPlot version 11.0. For the gene expression data, bacteria were exposed to four independent zeolite membranes and four independent AgNP-ZM, and changes in expression that were two-fold or greater are considered statistically significant. In the figures, the number of AgNP-ZM used for each experiment and the statistics are included.

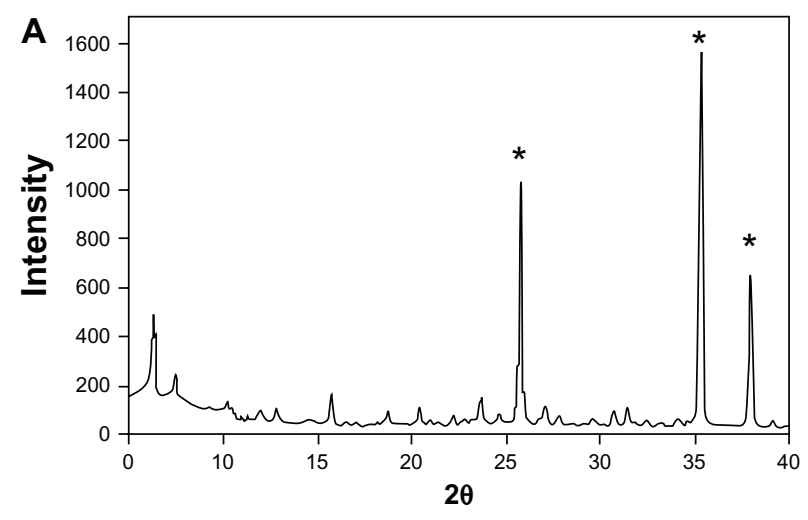

B

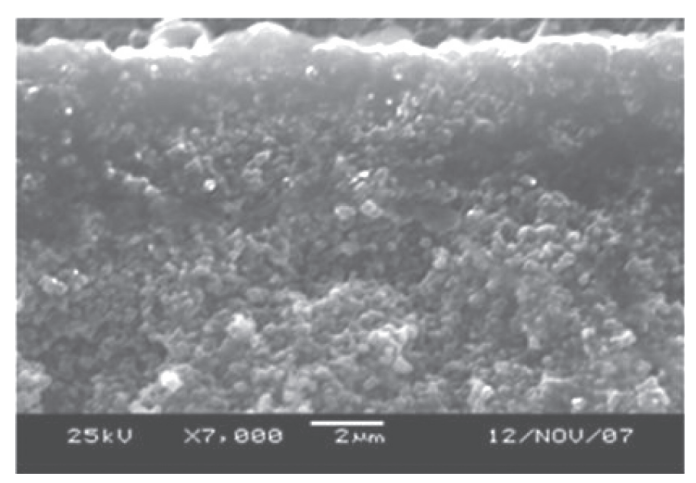

Figure I (A) Powder diffraction pattern of a zeolite membrane grown on an alumina support (the strongest peaks marked with an asterisk are due to the alumina, the rest are zeolite peaks. (B) Cross-section of the zeolite/alumina membrane by scanning electron microscopy.

\section{Results}

\section{AgNP-ZM synthesis and characterization}

Synthesis of AgNP-ZM starts with the synthesis of porous alumina supports, on which a seeded layer of zeolite is deposited. ${ }^{13}$ The zeolite membrane is then grown on the seeded side via secondary hydrothermal growth. Figure $1 \mathrm{~A}$ shows the powder $x$-ray pattern of a typical membrane. The three strong peaks (marked with an asterisk) arise from the alumina support. All of the other peaks are from the zeolite, the major phase being zeolite $\mathrm{Y}$ with minor quantities of zeolite A (strongest peak $7^{\circ} 2 \theta$ ). Figure $1 \mathrm{~B}$ shows a scanning electron microscopic cross-sectional image of the membrane with the dense $2-3 \mu \mathrm{m}$ layer of zeolite on the porous alumina ( $2 \mathrm{~mm}$ ). In order to make the AgNP, the zeolite membrane is ion-exchanged with $\mathrm{Ag}^{+}$, reduced with hydrazine to make Ag nanoclusters on the zeolite membrane, and extensively ion-exchanged with $\mathrm{Na}^{+}$to remove any unreacted $\mathrm{Ag}^{+}$. Figure 2A shows a scanning electron microscopic top view of the AgNP-ZM, and Figure 2B is a magnified image that clearly shows the presence of $\mathrm{Ag}$ clusters on the zeolite $(<50 \mathrm{~nm})$. Figure $2 \mathrm{C}$ is the elemental analysis of the surface of the membrane showing the presence of $\mathrm{Ag}, \mathrm{Si}$, and $\mathrm{Al}$. 


\section{A}

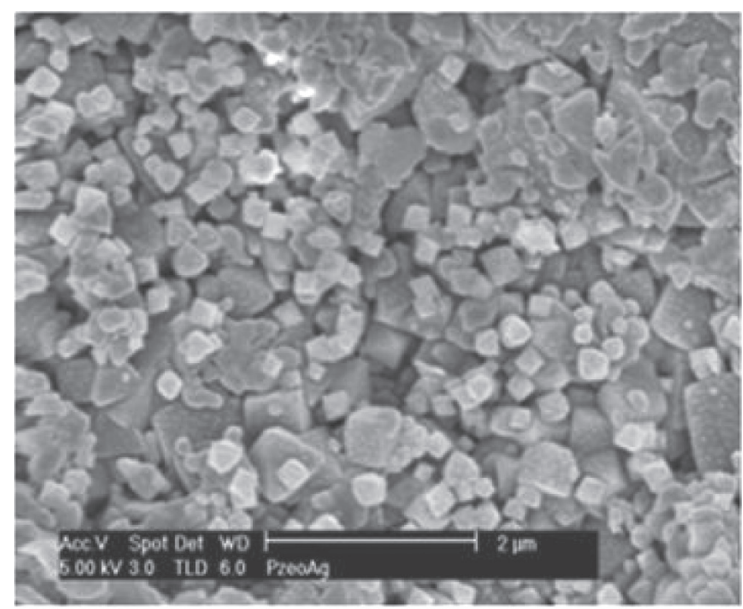

B

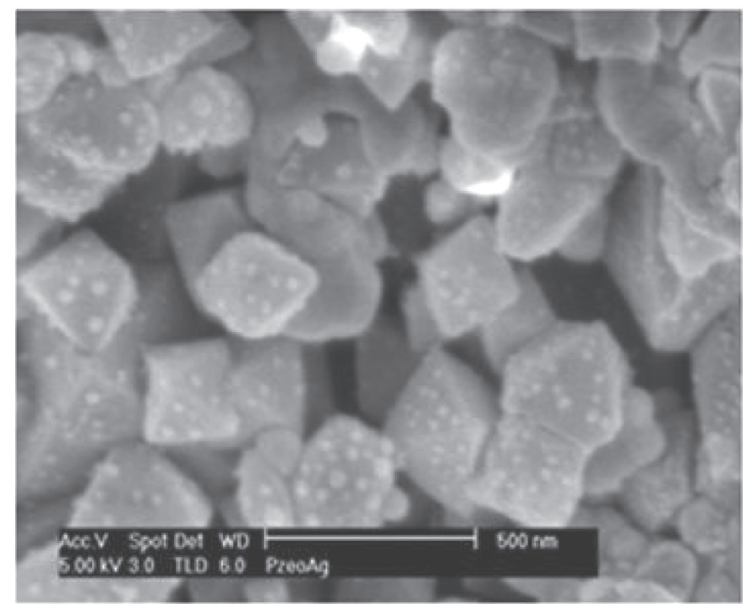

C

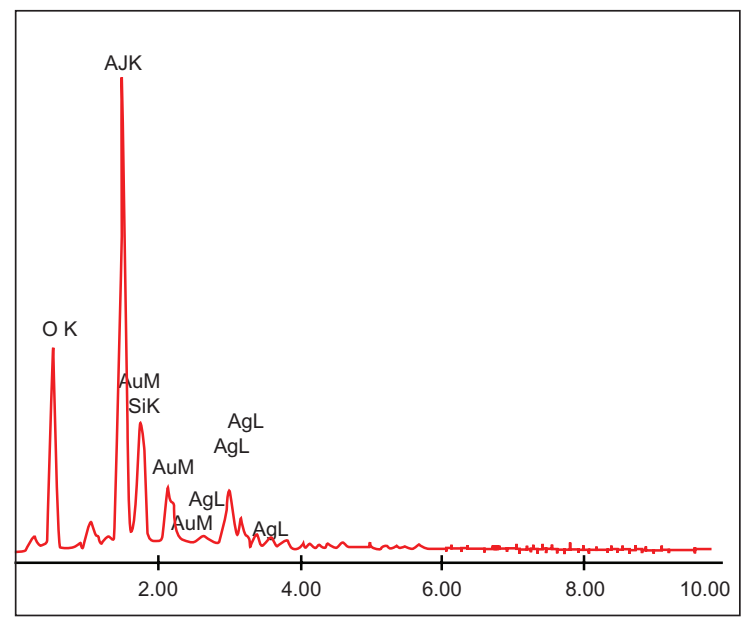

Figure 2 (A) Top view of the zeolite part of the silver-loaded zeolite/alumina membrane by scanning electron microscopy. (B) Magnified image of the top view of $\mathbf{A}$ showing discrete $\mathrm{Ag}$ particles on the zeolite. (C) Elemental analysis of the silver nanoparticles embedded in zeolite membranes, showing the presence of $\mathrm{Ag}$, $\mathrm{Si}$, and $\mathrm{Al}$.

The AgNP-ZM were incubated in LB broth $(5 \mathrm{~mL})$, and the amount of $\mathrm{Ag}^{+}$released over time was analyzed by elemental analysis. In order to estimate an upper limit of the amount of $\mathrm{Ag}^{+}$that can be released from the membrane, freshly prepared (autoclaved) AgNP-ZM were exposed to
LB broth for 48 hours under gentle shaking and the amount of $\mathrm{Ag}^{+}$was found to be approximately $20 \mathrm{ppm}$. When this same AgNP-ZM was exposed to media for 30 minutes for

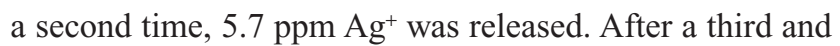
fourth exposure (sample autoclaved prior to each exposure) of the same AgNP-ZM for 30-minutes and 60-minutes, contact with media released 1.9 and $1.7 \mathrm{ppm}$ of $\mathrm{Ag}^{+}$, respectively. The goal of these elemental analysis studies was to evaluate an upper limit upon single exposure for an extended time period ( 48 hours), and to demonstrate that the AgNP-ZM have a large reservoir of $\mathrm{Ag}$ (primarily due to the large internal surface area of the zeolite) so that even a second, third, and fourth exposure leads to release of $\mathrm{Ag}^{+}$at ppm levels.

\section{Interaction of AgNP-ZM with E. coli}

Antibacterial activity

E. coli was incubated alone, with a control zeolite membrane, and with a freshly prepared AgNP-ZM to determine and
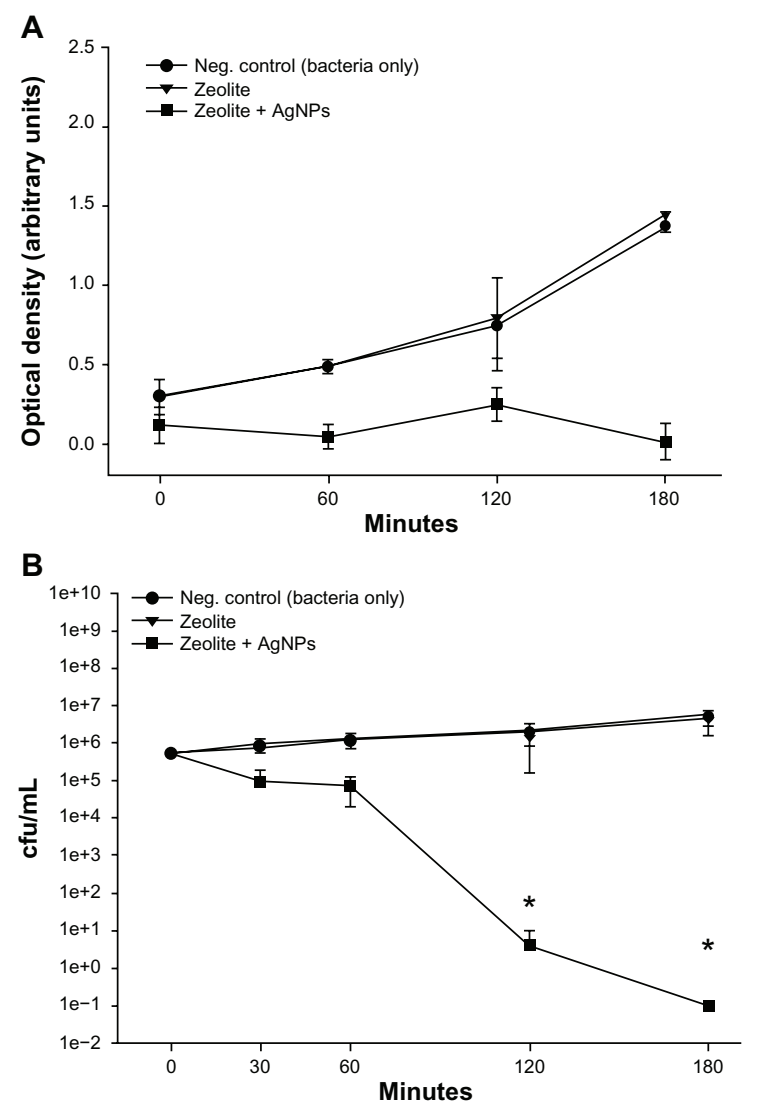

Figure 3 (A) Turbidity analyses of supernatant samples from unexposed Escherichia coli and $E$. coli exposed to zeolite controls or zeolite-supported silver nanoparticles over time. Values are expressed as the mean and standard deviation of two experiments. (B) Enumeration of viable $E$. coli over time upon incubation with zeolite supports containing silver nanoparticles and controls.

Notes: *Significant differences versus zeolite membrane controls, $n=3$, freshlyprepared zeolite supports containing silver nanoparticles, $P<0.05$.

Abbreviation: $\mathrm{cfu} / \mathrm{mL}$, colony forming units per milliliter. 
compare the antibacterial activity of AgNP-ZM. Turbidity measurements performed on two separate occasions using freshly prepared AgNP-ZM revealed that bacterial growth was completely inhibited over a three-hour incubation period when E. coli was exposed to AgNP-ZM (optical density about 0.4 ), whereas with bacteria only and zeolite supports, proliferation increased over time, as shown in Figure 3A. Figure 3B shows the number of colonies after incubation with controls or AgNP-ZM, and a significant decrease in E. coli viability was observed over a three-hour period, although a decrease in bacterial viability was noted with AgNP-ZM after 30 minutes. All of the data in Figure 3B were obtained with one freshly prepared AgNP-ZM on three separate occasions.

To determine if antibacterial action was contactdependent, a zeolite membrane control and two AgNP-ZM were incubated with $5 \mathrm{~mL}$ of LB broth for three hours. The membranes were then removed, and the conditioned LB broth $(5 \mathrm{~mL})$ was collected. Bacterial cultures which had been adjusted to about $1 \times 10^{5}$ cells $/ \mathrm{mL}$ in $5 \mathrm{~mL}$ of LB broth were pelleted by centrifugation. The pellet was vortexed, and the conditioned broth $(5 \mathrm{~mL})$ was then applied to the
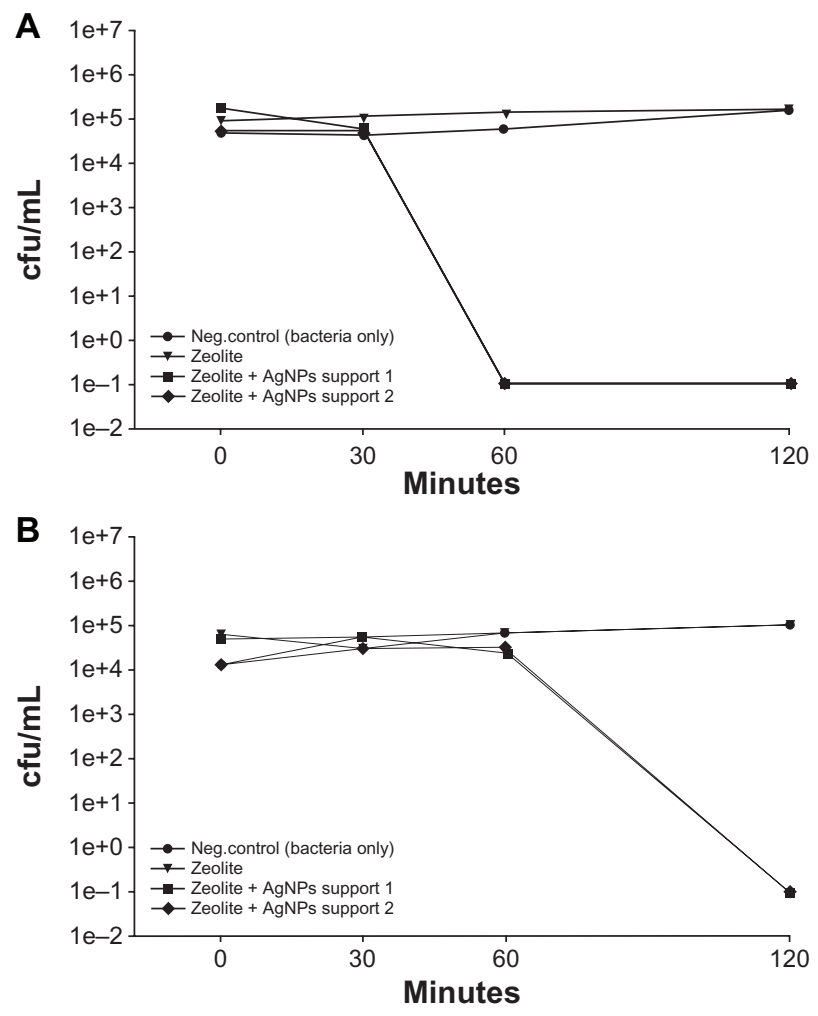

Figure 4 (A) Viability of Escherichia coli after exposure to supernatants collected from two zeolite supports containing silver nanoparticles and zeolite controls that were soaked in Luria Bertani media for three hours. (B) Viability of $E$. coli after exposure to two zeolite supports containing silver nanoparticles that were separated from bacteria using transwell plates. Zeolite supports containing silver nanoparticles are listed as zeolite + silver nanoparticle support I and support 2 in the Figure. Abbreviation: $\mathrm{cfu} / \mathrm{mL}$, colony forming units per milliliter. culture. As Figure 4A shows, all E. coli were nonviable within 60 minutes in medium conditioned with AgNP-ZM. Medium-conditioned with zeolite membranes alone had no observable effect on bacterial viability. Figure 4B illustrates that for bacteria separated from the zeolite membranes using transwell plates containing inserts with a pore size of $0.4 \mu \mathrm{m}$, death was evident within 120 minutes when AgNP-ZM were used, while controls grew normally. To ensure that bacteria were unable to traverse the transwell membrane, media from the bottom chamber were sampled from all experimental treatments and plated for growth on LB agar, and no colonies were observed (data not shown).

The antibacterial activity of a single AgNP-ZM was tested a total of six times in order to evaluate the feasibility of repeated use of a membrane. The support was sterilized by steam autoclave between each use. After the AgNP-ZM had been used three or four times, the viability of $E$. coli cultures seeded at a concentration of approximately $1 \times 10^{6} \mathrm{cfu} / \mathrm{mL}$ was reduced to $0 \mathrm{cfu} / \mathrm{mL}$ within two hours (Figure 5 ). However, after four or more uses, complete death was apparent after three hours of incubation.

\section{Gene expression by E. coli exposed to AgNP-ZM}

Gene expression arrays revealed significant differences between E. coli exposed to AgNP-ZM versus zeolite membranes. A total of 145 genes were upregulated greater than two-fold, while 170 genes were downregulated (Supplemental Tables 2 and 3 , respectively). Selected genes which were upregulated or downregulated by at least three-fold are included in Tables 1 and 2, respectively. Both copper transporter gene $\operatorname{cop} A$ and magnesium transporter gene $m g t A$ were upregulated over

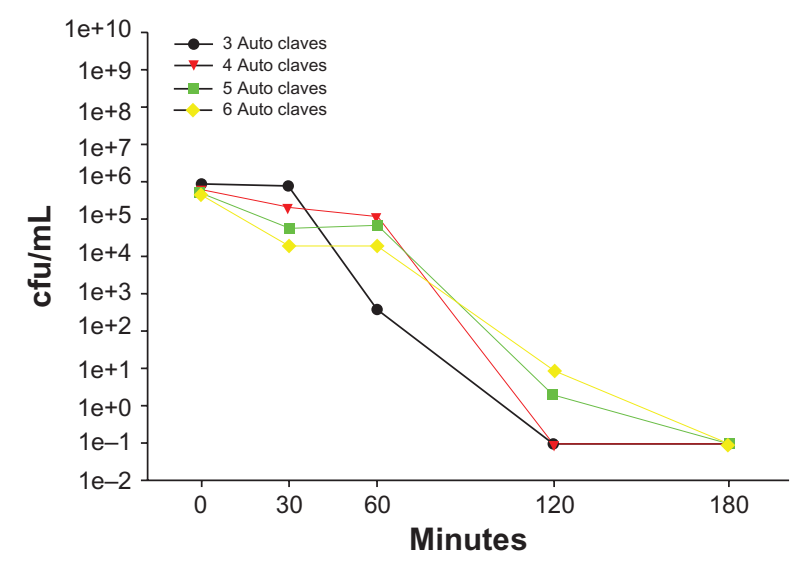

Figure 5 Escherichia coli at a concentration of $\mathrm{I} \times 10^{6} \mathrm{cfu} / \mathrm{mL}$ was incubated with the same zeolite supports containing silver nanoparticles six consecutive times, with autoclave sterilization between each use. Bacterial viability was determined using plate counts.

Abbreviation: $\mathrm{cfu} / \mathrm{mL}$, colony forming units per milliliter. 
Table I Increases in Escherichia coli gene expression in response to 30-minute exposures to four independent zeolite supports containing silver nanoparticles versus $E$. coli exposed to four independent zeolite controls

\begin{tabular}{|c|c|c|c|}
\hline $\begin{array}{l}\text { Gene } \\
\text { name }\end{array}$ & Gene product & $\begin{array}{l}\text { Fold change } \\
\text { AgNP-ZM vs zeolite }\end{array}$ & Description \\
\hline cysP & Thiosulfate transporter subunit & 14.9 & Thiosulfate binding protein \\
\hline cysW & Sulfate/thiosulfate transporter subunit & 11.9 & Sulfate transport system permease $\mathrm{W}$ protein \\
\hline copA & Copper transporter & 10.8 & Putative ATPase \\
\hline cysA & Sulfate/thiosulfate transporter subunit & 10.3 & $\begin{array}{l}\text { ATP-binding component of sulfate permease A protein; } \\
\text { chromate resistance }\end{array}$ \\
\hline hemH & Ferrochelatase & 9.5 & Ferrochelatase: final enzyme of heme biosynthesis \\
\hline$m g t A$ & Magnesium transporter & 9.0 & Mg2+ transport ATPase, P-type I \\
\hline cys $D$ & Sulfate adenylyltransferase, subunit 2 & 9.0 & ATP:sulfurylase \\
\hline$c y s U$ & Sulfate/thiosulfate transporter subunit & 9.0 & Sulfate, thiosulfate transport system permease $T$ protein \\
\hline cys] & Sulfite reductase, alpha subunit, flavoprotein & 8.7 & Sulfite reductase \\
\hline marA & $\begin{array}{l}\text { DNA-binding transcriptional dual activator } \\
\text { of multiple antibiotic resistance }\end{array}$ & 8.1 & $\begin{array}{l}\text { Multiple antibiotic resistance; transcriptional activator } \\
\text { of defense systems }\end{array}$ \\
\hline zraP & Zn-binding periplasmic protein & 7.9 & orf, hypothetical protein \\
\hline $\operatorname{trx} C$ & Thioredoxin 2 & 7.8 & Putative thioredoxin-like protein \\
\hline grxA & $\begin{array}{l}\text { Glutaredoxin I, redox coenzyme for } \\
\text { ribonucleotide reductase (RNRIa) }\end{array}$ & 7.6 & $\begin{array}{l}\text { Glutaredoxin I redox coenzyme for glutathione- } \\
\text { dependent ribonucleotide reductase }\end{array}$ \\
\hline marR & $\begin{array}{l}\text { DNA-binding transcriptional repressor } \\
\text { of multiple antibiotic resistance }\end{array}$ & 6.8 & $\begin{array}{l}\text { Multiple antibiotic resistance protein; repressor of mar } \\
\text { operon }\end{array}$ \\
\hline $\mathrm{cueO}$ & Multicopper oxidase (laccase) & 6.7 & orf, hypothetical protein \\
\hline cysl & $\begin{array}{l}\text { Sulfite reductase, beta subunit, } \\
\text { NAD(P)-binding, heme-binding }\end{array}$ & 6.1 & Sulfite reductase, alpha subunit \\
\hline cusF & Periplasmic copper-binding protein & 5.9 & orf, hypothetical protein \\
\hline cysH & $3^{\prime}$-phosphoadenosine $5^{\prime}$-phosphosulfate reductase & 5.7 & 3-phosphoadenosine 5-phosphosulfate reductase \\
\hline $\operatorname{ars} R$ & DNA-binding transcriptional repressor & 5.6 & Transcriptional repressor of chromosomal ars operon \\
\hline $\operatorname{ars} B$ & Arsenite/antimonite transporter & 4.2 & Arsenical pump membrane protein \\
\hline $\operatorname{sox} R$ & $\begin{array}{l}\text { DNA-binding transcriptional dual regulator, } \\
\text { Fe-S center for redox-sensing }\end{array}$ & 4.2 & Redox-sensing activator of soxS \\
\hline $\operatorname{ars} C$ & Arsenate reductase & 3.8 & Arsenate reductase \\
\hline cusB & $\begin{array}{l}\text { Copper/silver efflux system, membrane } \\
\text { fusion protein }\end{array}$ & 3.1 & Putative resistance protein \\
\hline cusC & $\begin{array}{l}\text { Copper/silver efflux system, outer } \\
\text { membrane component }\end{array}$ & 3.0 & Putative resistance protein \\
\hline
\end{tabular}

nine-fold. The genes which encode the antioxidants thioredoxin and glutaredoxin were also upregulated greater than about 7.5-fold compared with zeolite controls. In addition, several genes encoding proteins involved with sulfur transport, ie, $c y s W, c y s A, c y s D$, and $c y s U$, were upregulated greater than nine-fold (Table 1). Genes coding for multiple antibiotic resistance (marA and marR) were increased approximately eight-fold and seven-fold, respectively (Table 1). Several genes associated with iron transport, including fep $G, f e c R, f e p C$, $f e p A, f h u E$, and $f h u C$, were downregulated (Table 2), although the gene expression of hemH (coding for ferrochelatase) was upregulated about 10-fold (Table 1) in E. coli exposed to AgNP-ZM compared with zeolite membranes.

\section{Gene expression in E. coli changes with AgNP-ZM use} Quantitative reverse transcriptase PCR was used to confirm gene expression microarray data. Selected genes representing those involved with metal transport, resistance, and oxidative stress were analyzed in order to identify possible mechanisms of toxicity induced by exposure to AgNP-ZM. Table 3 reports quantitative reverse transcriptase PCR data for genes encoding copper-silver efflux, glutaredoxin, multicopper oxidase, and thioredoxin, and their expression levels after each support use. With progressive use of AgNP-ZM, expression of the gene that encodes glutaredoxin decreased (fold-change of approximately 14 and 2, and virtually no change for trials 1,2 , and 3, respectively). The expression of thioredoxin was increased by approximately five-fold for E. coli exposed to AgNP-ZM compared with bacteria exposed to zeolite membranes alone for the first use, but for the second and third uses there was virtually no change in gene expression. Increased expression of the gene encoding multicopper oxidase remained significant with each support use, although expression decreased by approximately 
Table 2 Decreases in Escherichia coli gene expression in response to 30-minute exposures to four independent zeolite supports containing silver nanoparticles versus $E$. coli exposed to four independent zeolite controls

\begin{tabular}{llll}
\hline $\begin{array}{l}\text { Gene } \\
\text { Name }\end{array}$ & Gene product & $\begin{array}{l}\text { Fold change } \\
\text { AgNP-ZM vs zeolite }\end{array}$ & Description \\
\hline fepG & Iron-enterobactin transporter subunit & -12.6 & Ferric enterobactin transport protein \\
fes & Enterobactin/ferric enterobactin esterase & -8.4 & Enterochelin esterase \\
cirA & Ferric iron-catecholate outer membrane & -7.1 & Outer membrane receptor for iron-regulated colicin \\
& transporter & & I receptor; porin; requires tonB gene product \\
fecR & KpLE2 phage-like element; transmembrane & -5.9 & Regulator for fec operon, periplasmic \\
& signal transducer for ferric citrate transport & & \\
fepC & Iron-enterobactin transporter subunit & -5.6 & ATP-binding component of ferric enterobactin \\
& & & transport \\
fes & Enterobactin/ferric enterobactin esterase & -5.6 & Enterochelin esterase \\
fepA & Iron-enterobactin outer membrane transporter & -5.4 & Outer membrane receptor for ferric enterobactin \\
fepD & Iron-enterobactin transporter subunit & -4.7 & Ferric enterobactin \\
fhuE & Ferric-rhodotorulic acid outer membrane & -4.0 & Outer membrane receptor for ferric iron uptake \\
& transporter & & Ferric enterobactin \\
fepB & Iron-enterobactin transporter subunit & -3.7 & Superoxide dismutase, manganese \\
sodA & Superoxide dismutase, Mn & -3.1 & ATP-binding component of hydroxymate-dependent \\
fhuC & iron-hydroxamate transporter subunit & -3.0 & iron transport \\
\end{tabular}

half with latter uses (44-fold, 33-fold, and 16-fold). Gene expression of cusC, which encodes copper-silver efflux, fluctuated slightly with each use (approximately 2-fold, 4-fold, and 2.5-fold for trials 1, 2, and 3, respectively). These experiments were done with a single AgNP-ZM on three separate occasions.

\section{Interaction of AgNP-ZM with other bacteria}

The primary goal of this paper was to understand the interaction of AgNP-ZM with E. coli XL-blue, which is a laboratory strain. We also did some preliminary work using MRSA. Exposure to AgNP-ZM resulted in reduced replication, as interpreted by the lack of increase in supernatant turbidity compared with controls, although the killing efficiency of the AgNP-ZM was found to be less potent compared with $E$. coli over the same exposure period (180 minutes). These data are shown in Figure 6. The gene expression studies were performed with $E$. coli, although further experimentation is underway using other clinically relevant bacterial strains.

\section{Discussion}

The discussion primarily focuses on the properties of the AgNP-ZM and its effect on E. coli.

\section{Release of $\mathrm{Ag}^{+}$from AgNP-ZM}

In our previous study, ${ }^{8}$ we did not address the issue of the interactions between bacteria and AgNP-ZM. Our preliminary data indicate that AgNP-ZM were bacteriostatic against MRSA, a Gram-positive clinically relevant strain of $S$. aureus. However, the bactericidal properties against this bacterium were less potent compared with Gram-negative $E$. coli. We hypothesize that cell wall differences between these two bacteria may account for the differences in bacterial

Table 3 Quantitative reverse transcriptase polymerase chain reaction analyses of select genes after three independent trials of zeolite support-containing silver nanoparticles. Escherichia coli at a concentration of $\mathrm{I} \times 10^{8}$ colony forming units $/ \mathrm{mL}$ was exposed to silver nanoparticles embedded in zeolite membranes or zeolite membrane controls for 45 minutes prior to RNA isolation and analyses. Values are fold-change \pm standard deviation

\begin{tabular}{lrrr}
\hline Gene product (gene name) & \multicolumn{4}{l}{ Gene expression fold increase } & \\
\cline { 2 - 4 } & \multicolumn{1}{l}{ Zeolite supported AgNP versus zeolite control } \\
\cline { 2 - 4 } & \multicolumn{1}{l}{ Trial I } & Trial 2 & Trial 3 \\
\hline Copper-silver efflux (cusC) & $2.1 I \pm 0.02$ & $3.93 \pm 1.12$ & $2.68 \pm 0.55$ \\
Glutaredoxin (grxA) & $14.64 \pm 1.16$ & $2.29 \pm 0.26$ & $1.22 \pm 0.34$ \\
Multicopper oxidase (cueO) & $43.90 \pm 5.92$ & $33.60 \pm 0.89$ & $16.41 \pm 0.58$ \\
Thioredoxin (trxC) & $5.30 \pm 0.47$ & $1.35 \pm 0.15$ & $0.99 \pm 0.18$ \\
\hline
\end{tabular}




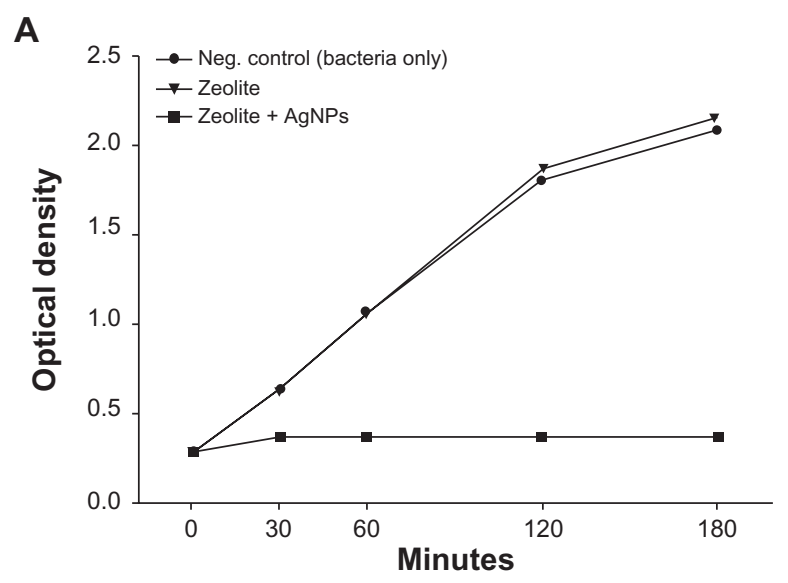

B

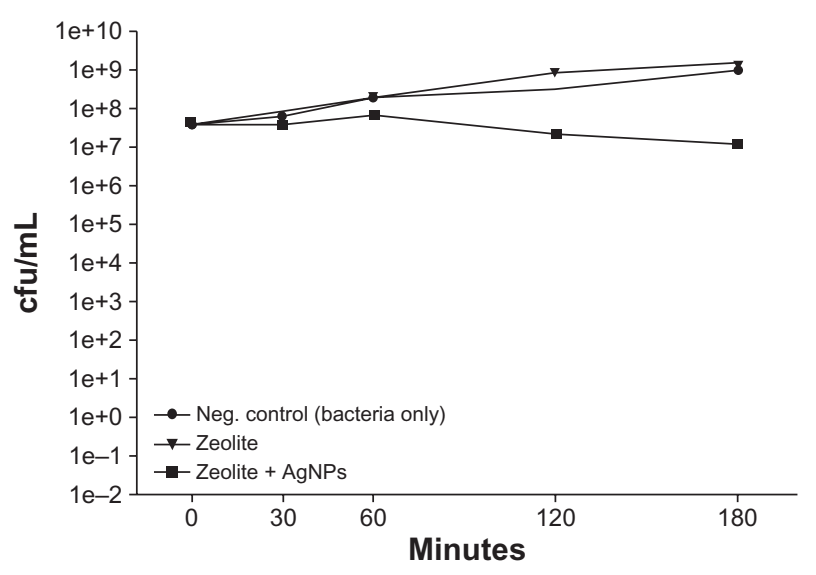

Figure 6 Growth and viability of Staphylococcus aureus alone, exposed to a zeolite membrane, or exposed to zeolite supports containing silver nanoparticles was evaluated over time. (A) Turbidity was analyzed after 30,60, 120 or 180 minutes of exposure to a single zeolite support containing silver nanoparticles. (B) Bacterial viability was measured after $30,60,120$, and 180 minutes of exposure to a single zeolite support containing silver nanoparticles.

Abbreviation: $\mathrm{cfu} / \mathrm{mL}$, colony forming units per milliliter.

viability upon exposure to AgNP-ZM, and studies are underway to investigate these findings. It is clear from the present study (Figure 4) that reduction of $E$. coli growth and viability does not require contact with the membrane. This is in contrast with the findings of Su et al, ${ }^{6}$ who found that $\mathrm{Ag} /$ clay-conditioned supernatants did not have appreciable antibacterial activity. With freshly prepared AgNP-ZM, we found that the release of $\mathrm{Ag}^{+}$into the broth can be as high as 20 ppm after 48 hours. Since the zeolite membranes were extensively ion-exchanged with $\mathrm{Na}^{+}$prior to these experiments, any $\mathrm{Ag}^{+}$in solution would have to occur by AgNP oxidation and release. Slow release of $\mathrm{Ag}^{+}$from the AgNP-ZM is also supported by the observation that bacteria sequestered in the transwell plates were not killed as quickly as those incubated with supernatants conditioned for three hours (Figure 4). It is known that solutions of $\mathrm{Ag}^{+}$at $0.05 \mathrm{ppm}$ result in complete reduction of $E$. coli viability within two hours. ${ }^{14}$ Oxidation of AgNP over time and release of $\mathrm{Ag}^{+}$in less than 30 minutes has been noted. ${ }^{4}$ With each AgNP-ZM, efficacy of the membranes decreased as well upon repeated use (Figure 5). $\mathrm{Ag}^{+}$released into media after the second, third, and fourth use was 5.7, 1.9, and $1.7 \mathrm{ppm}$, for 30-, 30-, and 60-minute exposures. There is clearly a decrease at the 30-minute exposure level between the second and third use, and it took twice as long (60 minutes) for the fourth use to match the release of the third use. Thus, we hypothesize that the bactericidal effects of AgNP-ZM are delayed due to reduction in the amount of $\mathrm{Ag}^{+}$released from AgNP-ZM with repeated use. As is evident from the scanning electron microscopy images (Figure 2B), there is a distribution of sizes of AgNP. Smaller AgNP are expected to undergo faster dissolution than larger particles, thus after each use, the $\mathrm{Ag}^{+}$ release should decrease. In addition, autoclaving could alter the surface of the AgNP, such as the formation of insoluble hydroxides or oxides. Interestingly, it has been reported that nanosilver bandages exposed to temperatures $>90^{\circ} \mathrm{C}$ have diminished bactericidal activity. ${ }^{15}$ Other sterilization measures, such as ultraviolet light, are also problematic, because of the photochemistry of silver. We also used ethanol for decontamination, as reported above.

\section{Disruption of oxidative balance}

Several research groups studying AgNP have proposed that their antibacterial activity is due to the formation of reactive oxygen species. The mechanism of bacterial death was found to be a result of persistent surface free radicals found on $\mathrm{AgNP}$, and that the antibacterial activity of both AgNP and $\mathrm{Ag}^{+}$could be reversed by n-acetylcysteine. ${ }^{16}$ The mechanism of toxicity of AgNP in clay was proposed to be cell membrane disruption caused by the generation of reactive oxygen species, and when incubated with the antioxidant, glutathione, their viability was restored. ${ }^{6}$ When bacterial reporter strains specifically responding to superoxide radicals were incubated with 100-300 ppm $\mathrm{Ag}^{+}$, it was apparent that the mechanism of antibacterial activity was via reactive oxygen species, specifically superoxide, which formed after perturbation of the electron transport chain. ${ }^{17}$ However, gene expression microarrays in the current study revealed downregulation of sodA, encoding a superoxide dismutase (3.1-fold decrease), which suggests that superoxide may not be the predominant reactive oxygen species driving bacterial oxidative stress. On the other hand, upregulation of expression of thioredoxin and glutaredoxin, which are crucial to maintaining oxidative balance, was noted after E. coli was exposed to AgNP-ZM (Table 3). Several genes associated with sulfur species trans- 
port and reduction were correlated with the multiple use of the AgNP-ZM. In the presence of silver $\left(\mathrm{Ag}^{+}\right)$, bacteria may adjust sulfur pools to accommodate the synthesis of sulfurcontaining antioxidants.

Genes associated with iron transport (fep genes) were downregulated, while hemH, which codes for ferrochelatase and plays an important role in heme synthesis, was upregulated. A possible response mechanism to the increased presence of $\mathrm{Ag}^{+}$is that the bacteria decrease the available pools of intracellular iron by increasing expression of ferrochelatase, which tightly binds $\mathrm{Fe}^{2+}$, to combat and reduce oxidative stress. ${ }^{18,19}$ The downregulation of genes with a role in iron reduction and iron release from proteins further suggests that the bacteria are attempting to control the intracellular levels of $\mathrm{Fe}^{2+},{ }^{20}$ thereby reducing the amount of iron available for Fenton reactions. Attempts by bacteria to regulate and restore oxidative balance are also suggested by the upregulation of $\operatorname{sox} R$, which is involved in redox sensing and controlling expression of superoxide dismutase and other antioxidants. ${ }^{21,22}$

Several genes encoding for metal ion influx and intracellular metal transport and efflux were upregulated. E. coli exposed to AgNP-ZM upregulated $m g t A$, which encodes for proteins used for $\mathrm{Mg}^{2+}$ influx, and also upregulated ars $R$ and $\operatorname{ars} B$, which encode genes involved in arsenic resistance, but currently have no known role in silver toxicity. The gene $z r a P$, which encodes a protein used for zinc homeostasis and $\operatorname{cop} A$, which in turn encodes for an ATPase intracellular copper transporter, were both upregulated. Others have found that $\operatorname{cop} A$ is induced in the presence of silver salts, ${ }^{23}$ but does not appear to be involved in silver resistance. ${ }^{24}$ Thus, it is likely that the mechanisms of AgNP toxicity are similar to those for copper toxicity. Slawson et $\mathrm{al}^{25}$ reported that $\mathrm{Ag}^{+}$ toxicity was reduced when $\mathrm{Cu}^{2+}$ is also present, indicating that silver may compete with copper for entry into the cell. There appears to be some promiscuity of bacterial metal transport proteins, the functions of which have not been fully elucidated.

\section{Developing resistance to silver}

The genes known to encode silver resistance in $E$. coli are $y b d E$, $y l c D, y l c C, y l c B, y l c A$, and $y b c Z .{ }^{26}$ Most silver-resistant bacterial strains have developed tolerance by utilizing $\mathrm{Ag}^{+}$ ATPase efflux pumps and antiporters rather than chemical detoxification mechanisms.$^{27}$ However, in the current study, only $\operatorname{cus} C(y l c B)$ and $c u s F(y l c C)$, the genes encoding for copper-silver efflux outer membrane protein and periplasmic copper and silver binding proteins, respectively, were upregulated when the bacteria were exposed to AgNP-ZM as compared with zeolite membrane controls. Further, we were able to confirm the upregulation of copper-silver efflux outer membrane protein ( $c u s C$ ) gene transcripts using quantitative reverse transcriptase PCR, although expression levels fluctuated with AgNP-ZM use, which may be a result of variations in $\mathrm{Ag}^{+}$release. The increase in gene transcription of multiple antibiotic resistant genes marA and marR is remarkable. The increased expression of mar genes is associated with antibiotic resistance (including tetracycline and ampicillin resistance). ${ }^{28}$ This work indicates that multiple antibiotic resistance genes may also play a role in the evolution of silver resistance in $E$. coli, and warrant further investigation.

\section{Conclusion}

The concept of using intrazeolitic space for storage of specific molecules and their slow release has found many applications. For example, controlled release of the preservative, cresol, from zeolite was successfully demonstrated by Erikkson ${ }^{29}$ where $E$. coli and $S$. aureus viability was reduced. Another study demonstrated the feasibility of zeolites as a vehicle for drug delivery by releasing ketoprofen under different physiological conditions. ${ }^{30}$ We have shown that surface-modified zeolites can release paraquat under controlled conditions. ${ }^{31}$ However, this study is the first to demonstrate that zeolite membranes can serve as supports, and we demonstrate this functionality using AgNP for antibacterial use. The impact of using membranes is that such membranes can be grown on various supports, including plastics, cellulose, and metals. ${ }^{12}$ Possible uses of this technology could include antibacterial coatings for a wide variety of applications. Further, these membranes have the propensity to be tailored for controlled release, thus dictating the amount of cargo released into the environment. Gene expression studies suggest that the mechanism for the antibacterial activity of AgNP-ZM is centered around the depletion of cellular antioxidant capacity by gradual release of $\mathrm{Ag}^{+}$from zeolite membranes.

\section{Acknowledgments}

Support for this research was obtained through grants from the National Institute for Occupational Safety and Health and US Department of Agriculture/National Institute of Food and Agriculture. We are grateful to Drs Vijay Pancholi and Joanne Trgovcich for donating the bacterial cultures used in this study. We thank David Newsom and Dr Peter White at the Nationwide Children's Hospital's Biomedical Genomics Core for their assistance with the gene expression microarray assays and analyses. 


\section{Disclosure}

The authors report no conflicts of interest in this work.

\section{References}

1. Alexander JW. History of the medical use of silver. Surg Infect. 2009; 10(3):289-292.

2. Chen X, Schluesener HJ. Nanosilver: A nanoproduct in medical application. Toxicol Lett. 2008;176(1):1-12.

3. Baker C, Pradhan A, Pakstis L, Pochan DJ, Shah SI. Synthesis and antibacterial properties of silver nanoparticles. J Nanosci Nanotechnol. 2005;5(2):244-249.

4. Lok CN, Ho CM, Chen R, et al. Silver nanoparticles: Partial oxidation and antibacterial activities. J Biol Inorg Chem. 2007;12(4):527-534.

5. Choi $\mathrm{O}, \mathrm{Hu} \mathrm{Z}$. Size dependent and reactive oxygen species related nanosilver toxicity to nitrifying bacteria. Environ Sci Technol. 2008;42(12):4583-4588.

6. Su HL, Chou CC, Hung DJ, et al. The disruption of bacterial membrane integrity through ROS generation induced by nanohybrids of silver and clay. Biomaterials. 2009;30(30):5979-5987.

7. Liang Z, Das A, Hu Z. Bacterial response to a shock load of nanosilver in an activated sludge treatment system. Water Res. 2010;44(18): 5432-5438.

8. Sabbani S, Gallego-Perez D, Nagy A, Waldman WJ, Hansford D, Dutta PK. Synthesis of silver-zeolite films on micropatterned porous alumina and its application as an antimicrobial substrate. Micropor Mesopor Mat. 2010;135(1-3):131-136.

9. Fernández A, Soriano E, Hernández-Muñoz P, Gavara R. Migration of antimicrobial silver from composites of polylactide with silver zeolites. J Food Sci. 2010;75(3):E186-E193.

10. Kwakye-Awuah B, Williams C, Kenward MA, Radecka I. Antimicrobial action and efficiency of silver-loaded zeolite X. J Appl Microbiol. 2008;104(5):1516-1524

11. Shameli K, Ahmad MB, Zargar M, Yunus WM, Ibrahim NA. Fabrication of silver nanoparticles doped in the zeolite framework and antibacterial activity. Int J Nanomedicine. 2011;(6):331-341

12. Tavolaro A, Drioli E. Zeolite membranes. Adv Mater. 1999;11: 975-996.

13. White JC, Dutta PK, Shqau K, Verweij H. Synthesis of ultrathin zeolite Y membranes and their application for separation of carbon dioxide and nitrogen gases. Langmuir. 2010;(26):10287-10293.

14. Jung WK, Koo HC, Kim KW, Shin S, Kim SH, Park YH. Antibacterial activity and mechanism of action of the silver ion in Staphylococcus aureus and Escherichia coli. Appl Environ Microbiol. 2008;74(7): 2171-2178.
15. Landry BK, Nadworny PL, Omotoso OE, Maham Y, Burrell JC, Burrell RE. The kinetics of thermal instability in nanocrystalline silver and the effect of heat treatment on the antibacterial activity of nanocrystalline silver dressings. Biomaterials. 2009;30(36):6929-6939.

16. Kim JS, Kuk E, Yu KN, et al. Antimicrobial effects of silver nanoparticles. Nanomed Nanotech Biol Med. 2007;3(1):95-101.

17. Park HJ, Kim JY, Kim J, et al. Silver-ion-mediated reactive oxygen species generation affecting bactericidal activity. Water Res. 2009;43(4): 1027-1032.

18. Crichton RR, Wilmet S, Legssyer R, Ward RJ. Molecular and cellular mechanisms of iron homeostasis and toxicity in mammalian cells J Inorg Biochem. 2002;91(1):9-18.

19. Hunter GA, Sampson MP, Ferreira GC. Metal ion substrate inhibition of ferrochelatase. J Biol Chem. 2008;283(35):23685-23691.

20. Andrews SC. Iron storage in bacteria. Adv Microb Physiol. 1998;40: 281-351.

21. Ha U, Jin S. Expression of the soxR gene of Pseudomonas aeruginosa is inducible during infection of burn wounds in mice and is required to cause efficient bacteremia. Infect Immun. 1999;67(10):5324-5331.

22. Gort AS, Imlay JA. Balance between endogenous superoxide stress and antioxidant defenses. J Bacteriol. 1998;180(6):1402-1410.

23. Rensing C, Fan B, Sharma R, Mitra B, Rosen BP. CopA: An Escherichia coli Cu(I)-translocating P-type ATPase. Proc Natl Acad Sci U S A. 2000;97(2):652-656.

24. Franke S, Grass G, Nies DH. The product of the ybdE gene of the Escherichia coli chromosome is involved in detoxification of silver ions. Microbiology. 2001;147(4):965-972.

25. Slawson RM, Lee H, Trevors JT. Bacterial interactions with silver. BioMetals. 1990;3(3):151-154.

26. Silver S, Phung le T, Silver G. Silver as biocides in burn and wound dressings and bacterial resistance to silver compounds. J Ind Microbiol Bio technol. 2006;33(7):627-634.

27. Silver S. Bacterial silver resistance: Molecular biology and uses and misuses of silver compounds. FEMS Microbiol Rev. 2003;27(2-3): 341-353.

28. Okusu H, Ma D, Nikaido H. AcrAB efflux pump plays a major role in the antibiotic resistance phenotype of Escherichia coli multiple-antibioticresistance (Mar) mutants. J Bacteriol. 1996;178(1):306-308.

29. Eriksson H. Controlled release of preservatives using dealuminated zeolite Y. J Biochem Biophys Methods. 2008;70(6):1139-1144.

30. Rimoli MG, Rabaioli MR, Melisi D, et al. Synthetic zeolites as a new tool for drug delivery. J Biomed Mater Res A. 2008;87(1):156-164.

31. Zhang H, Kim Y, Dutta PK. Controlled release of paraquat from surfacemodified zeolite Y. Micropor Mesopor Mat. 2006;88(1-3):312-318. 


\section{Supplemental Methods RNA isolation}

Bacteria were collected from each well and pelleted at $4{ }^{\circ} \mathrm{C}$ in $15 \mathrm{~mL}$ centrifuge tubes at $3250 \times \mathrm{g}$ for 15 minutes. Supernatants were discarded and the pellets were homogenized in $5 \mathrm{~mL}$ Trizol for five minutes. Each tube was shaken vigorously for 30 seconds after the addition of $1 \mathrm{~mL}$ of chloroform. The tubes were incubated at room temperature for three minutes prior to centrifugation at $4^{\circ} \mathrm{C}$ and $3250 \times \mathrm{g}$ for $15 \mathrm{~min}-$ utes. The organic layer was then removed and placed into clean RNase free microfuge tubes. Equal amounts of 100\% ethanol were added to each tube and mixed by pipetting. RNA purification was then performed using RNeasy mini kits as per the manufacturer's instructions, during which DNase was added to remove contaminating DNA. At the final elution step, RNA was resuspended in $20 \mu \mathrm{L}$ of RNase-free $\mathrm{H}_{2} \mathrm{O}$ and stored at $-80^{\circ} \mathrm{C}$ until further use in gene expression arrays and

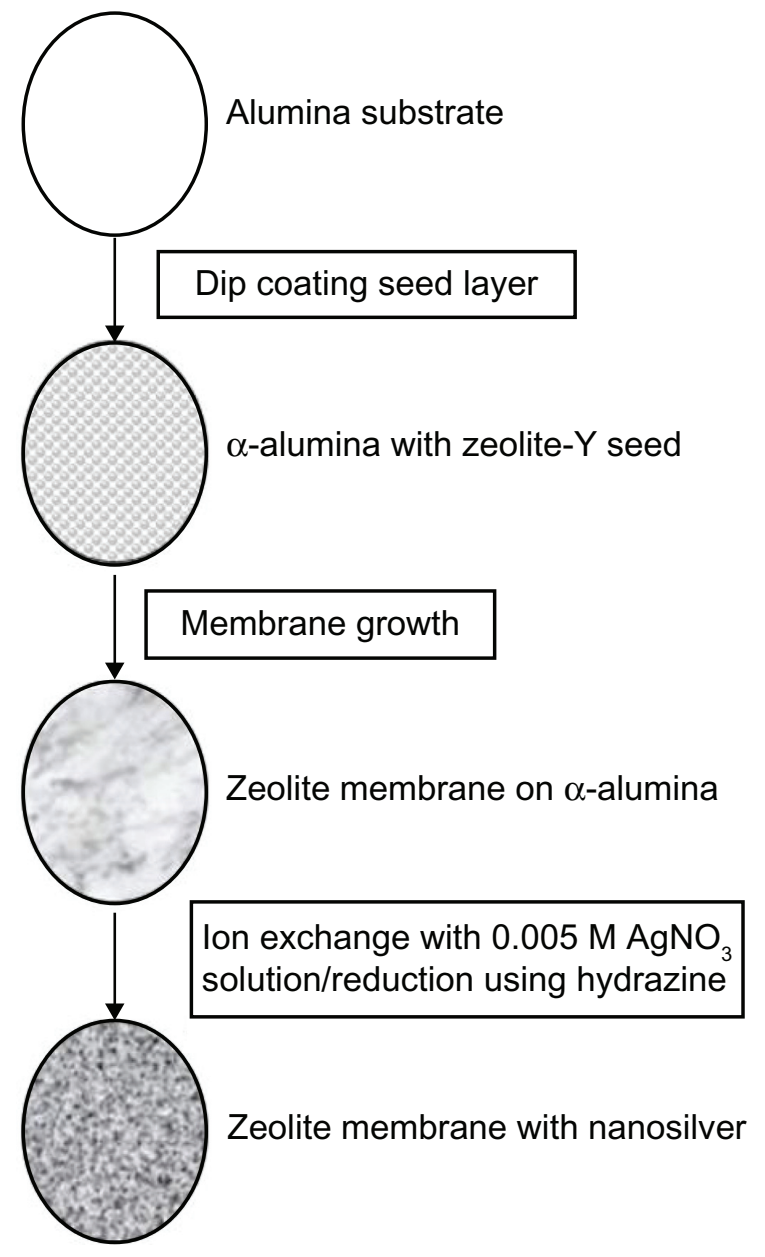

Figure SI Schematic of fabrication of zeolite support containing silver nanoparticles. Alumina supports were used as the substrate for zeolite membrane synthesis. Zeolite was grown into a continuous membrane by hydrothermal synthesis. Zeolite membranes were then ion-exchanged with $0.005 \mathrm{M} \mathrm{AgNO}_{3}$ solution, washed, and then reduced by hydrazine.

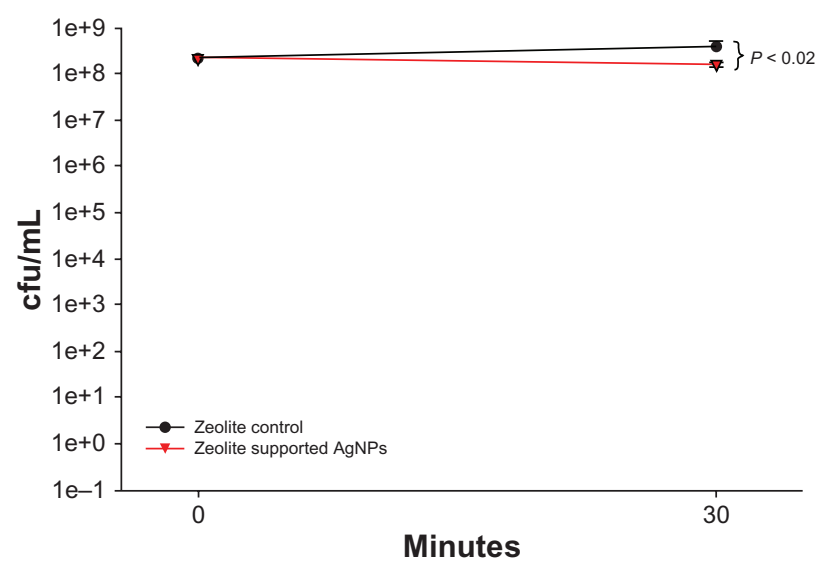

Figure S2 Viability of Escherichia coli after exposure to zeolite support containing silver nanoparticles for 30 minutes. The viability of $E$. coli was determined after exposure to zeolite support containing silver nanoparticles for 30 minutes. RNA was harvested from these experiments and used for the gene expression microarray analyses. Viability was significantly reduced after incubation with zeolite support containing silver nanoparticles for 30 minutes, compared with zeolite controls. Statistical significance was determined using the Student's $t$-test $(n=4$ for zeolite controls and zeolite support containing silver nanoparticles, $P<0.02$ ).

quantitative reverse transcription polymerase chain reaction experiments. The concentration of the samples provided was determined using the NanoDrop ${ }^{\circledR}$ ND-1000 ultraviolet-visible spectrophotometer.

\section{Gene arrays}

Microarray slides were hybridized overnight, washed, and then scanned with an Agilent G2505C microarray scanner. This high-resolution scanner features an industry-leading extended dynamic range of $10^{6}$ (20-bits) for high sensitivity scanning without saturation, low-level detection resulting from optimized precision optics, broad dynamic range, and minimal spectral cross talk that enables detection of weak features. The information about each probe on the array was extracted from the image data using Agilent Feature Extraction 10.9. This data was stored in Feature Extraction ".txt" files. The raw intensity values from these files were imported into the mathematical software package " $\mathrm{R}$ ", which is used for all data input, diagnostic plots, normalization, and quality checking steps of the analysis process using scripts developed inhouse specifically for this analysis. These scripts call on several Bioconductor packages (http://www.bioconductor.org/). Bioconductor is an open source and open development software project that provides tools for the analysis and comprehension of genomic data. ${ }^{1}$ Significance analyses of microarrays (SAM) is a powerful tool for analyzing microarray gene expression data useful for identifying differentially expressed genes between two conditions. ${ }^{2}$ SAM was used to calculate a test 
Table SI E. coli primer sequences for quantitative real-time PCR (QRT-PCR)

\begin{tabular}{|c|c|c|c|}
\hline Gene product (gene name) & Sequence & $\mathbf{T}_{m}(\mathbf{C})$ & Product size \\
\hline Multi copper oxidase $(c u e O) \mathrm{F}$ & TTCCGTATCTTGTCAGAAAATGGCA & 58.7 & $195 \mathrm{bp}$ \\
\hline Multi copper oxidase (cueO) $\mathrm{R}$ & TACCGTAAACCCTAACATCATCCCC & 58.2 & \\
\hline Thioredoxin $(\operatorname{tr} x \mathrm{C}) \mathrm{F}$ & ACACTCGACAAATTGCTGAAGGATG & 58.3 & 164 bp \\
\hline Thioredoxin $(\operatorname{trx} C) \mathrm{R}$ & AATTCACGTTCAGCTTCGGTATTCAC & 58.7 & \\
\hline Glutaredoxin $(g r x A) F$ & TTGCCCTTACTGTGTGCGTGC & 58.4 & $151 \mathrm{bp}$ \\
\hline Glutaredoxin $(g r x A) R$ & CGGCACGGTTTCTACGGGTT & 58.5 & \\
\hline Copper/silver efflux (cusC) $\mathrm{F}$ & TTATGAACAGAAAATCCAGAACGCCT & 58.3 & $228 \mathrm{bp}$ \\
\hline Copper/silver efflux (cusC) $\mathrm{R}$ & TAATTCAGATCAAGTAAAGTTTGTCGGGT & 58 & \\
\hline
\end{tabular}

Abbreviations: $\mathrm{F}=$ Forward sequence; $\mathrm{R}=$ Reverse sequence; $\mathrm{bp}=$ base pairs.

statistic for relative difference in gene expression based on permutation analysis of expression data and calculated a false discovery rate using the q-value method presented by Storey and Tibshirani. ${ }^{3}$ In outline, SAM identified statistically significant genes by carrying out gene-specific $t$-tests and computed a statistic for each gene. This test statistic measured the strength of the relationship between gene expression and a five-response variable. This analysis used no-parametric statistics, given that the data may not follow a normal distribution. The response variable described and grouped the data based on experimental conditions. In this method, repeated permutations of the data were used to determine if the expression of any gene is significantly related to the response. The use of permutation-based analysis accounted for correlations in genes and avoided parametric assumptions about the distribution of individual genes. For this experiment, SAM analysis was implemented in R using the Bioconductor Siggenes package. Also, Relative Log Expression values were computed for each probe set by comparing the expression value in each array against the median expression value for that probe set across all arrays. Gene expression arrays were analyzed using a $10 \%$ false discovery rate to generate the list of significantly differentially expressed genes. The q-values (false discovery rate) for each gene are provided in the results table, and the lower the value the more significant the result.

Table S2 Increases in E. coli gene expression in response to 30-minute exposures to four independent zeolite supports containing AgNPs versus $E$. coli exposed to four independent zeolite controls

\begin{tabular}{|c|c|c|}
\hline Gene product & $\begin{array}{l}\text { Fold change } \\
\text { AgNP-ZM } \\
\text { vs zeolite }\end{array}$ & Description \\
\hline Thiosulfate transporter subunit & 14.9 & Thiosulfate binding protein \\
\hline Predicted protein & 14.6 & Multiple antibiotic resistance protein \\
\hline Predicted transcriptional regulator & 13 & orf, hypothetical protein \\
\hline Sulfate/thiosulfate transporter subunit & 11.9 & Sulfate transport system permease $\mathrm{W}$ protein \\
\hline Copper transporter & 10.8 & Putative ATPase \\
\hline Sulfate/thiosulfate transporter subunit & 10.3 & $\begin{array}{l}\text { ATP-binding component of sulfate permease A protein; } \\
\text { chromate resistance }\end{array}$ \\
\hline Ferrochelatase & 9.5 & Ferrochelatase: final enzyme of heme biosynthesis \\
\hline Magnesium transporter & 9 & Mg2+ transport ATPase, P-type I \\
\hline Sulfate adenylyltransferase, subunit 2 & 9 & ATP:sulfurylase \\
\hline Sulfate/thiosulfate transporter subunit & 9 & Sulfate, thiosulfate transport system permease $T$ protein \\
\hline Predicted DNA-binding transcriptional regulator & 8.8 & orf, hypothetical protein \\
\hline Sulfite reductase, alpha subunit, flavoprotein & 8.7 & Sulfite reductase \\
\hline $\begin{array}{l}\text { DNA-binding transcriptional dual activator of multiple } \\
\text { antibiotic resistance }\end{array}$ & 8.1 & $\begin{array}{l}\text { Multiple antibiotic resistance; transcriptional activator of defense } \\
\text { systems }\end{array}$ \\
\hline Predicted inner membrane protein & 8.1 & Putative transport system permease protein \\
\hline Conserved protein & 8 & orf, hypothetical protein \\
\hline Predicted protein & 7.9 & orf, hypothetical protein \\
\hline Zn-binding periplasmic protein & 7.9 & orf, hypothetical protein \\
\hline Pseudo & 7.8 & Attaching and effacing protein, pathogenesis factor \\
\hline Thioredoxin 2 & 7.8 & Putative thioredoxin-like protein \\
\hline
\end{tabular}


Table S2 (Continued)

\begin{tabular}{|c|c|c|}
\hline Gene product & $\begin{array}{l}\text { Fold change } \\
\text { AgNP-ZM } \\
\text { vs zeolite }\end{array}$ & Description \\
\hline $\begin{array}{l}\text { Glutaredoxin I, redox coenzyme for ribonucleotide } \\
\text { reductase (RNRIa) }\end{array}$ & 7.6 & $\begin{array}{l}\text { Glutaredoxin I redox coenzyme for glutathione-dependent } \\
\text { ribonucleotide reductase }\end{array}$ \\
\hline Sulfate transporter subunit & 7.6 & Periplasmic sulfate-binding protein \\
\hline Predicted oxidoreductase with NAD(P)-binding & 7.2 & Putative oxidoreductase \\
\hline \multicolumn{3}{|l|}{ Rossmann-fold domain } \\
\hline Predicted cyanide hydratase & 7.1 & orf, hypothetical protein \\
\hline 5,10-methylenetetrahydrofolate reductase & 7.1 & 5, I0-methylenetetrahydrofolate reductase \\
\hline $\begin{array}{l}\text { DNA-binding transcriptional repressor of multiple antibiotic } \\
\text { resistance }\end{array}$ & 6.8 & Multiple antibiotic resistance protein; repressor of mar operon \\
\hline Multicopper oxidase (laccase) & 6.7 & orf, hypothetical protein \\
\hline Sulfite reductase, beta subunit, NAD(P)-binding, heme-binding & 6.1 & Sulfite reductase, alpha subunit \\
\hline Predicted quinol oxidase subunit & 6 & orf, hypothetical protein \\
\hline Predicted protein & 5.9 & orf, hypothetical protein \\
\hline Periplasmic copper-binding protein & 5.9 & orf, hypothetical protein \\
\hline $\begin{array}{l}\text { Alkyl hydroperoxide reductase, F52a subunit, } \\
\text { FAD/NAD(P)-binding }\end{array}$ & 5.8 & $\begin{array}{l}\text { Alkyl hydroperoxide reductase, F52a subunit; detoxification of } \\
\text { hydroperoxides }\end{array}$ \\
\hline Predicted DNA-binding transcriptional regulator & 5.8 & orf, hypothetical protein \\
\hline DNA-binding transcriptional activator, homocysteine-binding & 5.7 & Regulator for metE and metH \\
\hline $3^{\prime}$-phosphoadenosine $5^{\prime}$-phosphosulfate reductase & 5.7 & 3-phosphoadenosine 5-phosphosulfate reductase \\
\hline DNA-binding transcriptional repressor & 5.6 & Transcriptional repressor of chromosomal ars operon \\
\hline ISI transposase InsAB' & 5.6 & ISI protein InsB \\
\hline Conserved protein & 5.4 & orf, hypothetical protein \\
\hline Conserved protein & 5 & orf, hypothetical protein \\
\hline Predicted membrane protein & 4.9 & orf, hypothetical protein \\
\hline Sulfate adenylyltransferase, subunit I & 4.9 & ATP-sulfurylase \\
\hline Predicted protein & 4.4 & orf, hypothetical protein \\
\hline $\begin{array}{l}\text { Alcohol dehydrogenase class III/glutathione-dependent } \\
\text { formaldehyde dehydrogenase }\end{array}$ & 4.4 & Alcohol dehydrogenase class III; formaldehyde dehydrogenase \\
\hline N-ethylmaleimide reductase, FMN-linked & 4.3 & $\mathrm{~N}$-ethylmaleimide reductase \\
\hline Conserved protein & 4.3 & orf, hypothetical protein \\
\hline RNA polymerase, sigma 32 (sigma $\mathrm{H}$ ) factor & 4.3 & RNA polymerase, sigma \\
\hline Nitrate reductase I, beta (Fe-S) subunit & 4.2 & Nitrate reductase I, beta subunit \\
\hline Arsenite/antimonite transporter & 4.2 & Arsenical pump membrane protein \\
\hline $\begin{array}{l}\text { DNA-binding transcriptional dual regulator, Fe-S center } \\
\text { for redox-sensing }\end{array}$ & 4.2 & Redox-sensing activator of soxS \\
\hline Respiratory NADH dehydrogenase 2/cupric reductase & 3.9 & Respiratory NADH dehydrogenase \\
\hline Predicted inner membrane protein, part of terminus & 3.9 & Putative transport protein \\
\hline Envelope stress induced periplasmic protein & 3.8 & Periplasmic protein related to spheroblast formation \\
\hline $\begin{array}{l}\text { Fused fructose-specific PTS enzymes: IIA component/HPr } \\
\text { component }\end{array}$ & 3.8 & PTS system, fructose-specific IIA/fpr component \\
\hline Arsenate reductase & 3.8 & Arsenate reductase \\
\hline Fructose-I-phosphate kinase & 3.6 & Fructose-I-phosphate kinase \\
\hline DNA-binding transcriptional repressor & 3.6 & orf, hypothetical protein \\
\hline Predicted transporter & 3.6 & Part of a kinase \\
\hline Nitrate reductase I, alpha subunit & 3.6 & Nitrate reductase I, alpha subunit \\
\hline Predicted esterase & 3.5 & Putative esterase \\
\hline $\begin{array}{l}\text { Molybdenum-cofactor-assembly chaperone subunit } \\
\text { of nitrate reductase I }\end{array}$ & 3.5 & Nitrate reductase I, delta subunit, assembly function \\
\hline 3-oxoacyl-[acyl-carrier-protein] synthase II & 3.4 & 3-oxoacyl- \\
\hline DL-methionine transporter subunit & 3.3 & ATP-binding component of a transporter \\
\hline Predicted (D)-galactarate transporter & 3.3 & Putative transport protein \\
\hline Fused chorismate mutase T/prephenate dehydrogenase & 3.3 & Chorismate mutase-T and prephenate dehydrogenase \\
\hline Nitrate reductase I, gamma (cytochrome b(NR)) subunit & 3.2 & Nitrate reductase I, cytochrome b \\
\hline Fumarate hydratase (fumarase $\mathrm{C}$ ), aerobic Class II & 3.2 & Fumarase $\mathrm{C}=$ fumarate hydratase Class II; isozyme \\
\hline Copper/silver efflux system, membrane fusion protein & 3.1 & Putative resistance protein \\
\hline
\end{tabular}


Table S2 (Continued)

\begin{tabular}{|c|c|c|}
\hline Gene product & $\begin{array}{l}\text { Fold change } \\
\text { AgNP-ZM } \\
\text { vs zeolite }\end{array}$ & Description \\
\hline Membrane protein of efflux system & 3.1 & orf, hypothetical protein \\
\hline Copper/silver efflux system, outer membrane component & 3 & Putative resistance protein \\
\hline Regulator protein that represses frmRAB operon & 3 & Putative alpha helix chain \\
\hline Homoserine O-transsuccinylase & 3 & Homoserine transsuccinylase \\
\hline Predicted pirin-related protein & 3 & orf, hypothetical protein \\
\hline Fused nitric oxide dioxygenase/dihydropteridine reductase 2 & 3 & Dihydropteridine reductase, ferrisiderophore reductase activity \\
\hline Nitrite reductase, large subunit, NAD(P)H-binding & 2.9 & Nitrite reductase \\
\hline Predicted inner membrane protein & 2.9 & Putative transport protein \\
\hline Adenosine 5'-phosphosulfate kinase & 2.8 & Adenosine 5-phosphosulfate kinase \\
\hline Maltose regulon periplasmic protein & 2.8 & Periplasmic protein of mal regulon \\
\hline Conserved protein & 2.8 & orf, hypothetical protein \\
\hline Carbon-phosphorus lyase complex subunit & 2.8 & Phosphonate metabolism \\
\hline Maltose transporter subunit & 2.7 & $\begin{array}{l}\text { Periplasmic maltose-binding protein; substrate recognition for } \\
\text { transport and chemotaxis }\end{array}$ \\
\hline Fructuronate transporter & 2.7 & Gluconate transport system permease 3 \\
\hline $\begin{array}{l}\text { Predicted regulator of cell morphogenesis and } \\
\text { cell wall metabolism }\end{array}$ & 2.6 & orf, hypothetical protein \\
\hline DNA-binding transcriptional dual regulator, glycolate-binding & 2.6 & Transcriptional activator for glc operon \\
\hline Predicted endopeptidase & 2.6 & Heat shock protein, integral membrane protein \\
\hline Conserved protein & 2.6 & orf, hypothetical protein \\
\hline $\begin{array}{l}\text { Formate dehydrogenase-N, Fe-S (beta) subunit, } \\
\text { nitrate-inducible }\end{array}$ & 2.6 & $\begin{array}{l}\text { Formate dehydrogenase- } \mathrm{N} \text {, nitrate-inducible, iron-sulfur beta } \\
\text { subunit }\end{array}$ \\
\hline Predicted glucarate dehydratase & 2.6 & Putative glucarate dehydratase \\
\hline Calcium/sodium:proton antiporter & 2.5 & Sodium-calcium/proton antiporter \\
\hline Formate dehydrogenase- $\mathrm{N}$, alpha subunit, nitrate-inducible & 2.5 & Formate dehydrogenase- $\mathrm{N}$, nitrate-inducible, alpha subunit \\
\hline Gluconate transporter, high-affinity GNT I system & 2.5 & High-affinity transport of gluconate/gluconate permease \\
\hline Predicted peptidoglycan peptidase & 2.5 & orf, hypothetical protein \\
\hline $\begin{array}{l}\text { Formate dehydrogenase-N, cytochrome B556 } \\
\text { (gamma) subunit, nitrate-inducible }\end{array}$ & 2.4 & Formate dehydrogenase- $\mathrm{N}$, nitrate-inducible, cytochrome B556 \\
\hline el4 prophage; predicted DNA-binding transcriptional regulator & 2.4 & orf, hypothetical protein \\
\hline Nitrite reductase, $\mathrm{NAD}(\mathrm{P}) \mathrm{H}$-binding, small subunit & 2.4 & Nitrite reductase \\
\hline Predicted zinc-dependent peptidase & 2.4 & orf, hypothetical protein \\
\hline Conserved protein required for cell growth & 2.4 & orf, hypothetical protein \\
\hline Cystathionine gamma-synthase, PLP-dependent & 2.4 & Cystathionine gamma-synthase \\
\hline Conserved protein & 2.4 & orf, hypothetical protein \\
\hline L-serine deaminase I & 2.4 & L-serine deaminase \\
\hline Predicted reductase & 2.4 & Putative reductase \\
\hline Alpha-dehydro-beta-deoxy-D-glucarate aldolase & 2.4 & orf, hypothetical protein \\
\hline D-serine ammonia-lyase & 2.4 & D-serine dehydratase \\
\hline Serine endoprotease (protease Do), membrane-associated & 2.3 & Periplasmic serine protease Do; heat shock protein HtrA \\
\hline $\mathrm{NADH}$-azoreductase, FMN-dependent & 2.3 & Acyl carrier protein phosphodiesterase \\
\hline Isopentenyl diphosphate isomerase & 2.3 & Putative enzyme \\
\hline Nitrite reductase, $\mathrm{NAD}(\mathrm{P}) \mathrm{H}$-binding, small subunit & 2.3 & Nitrite reductase \\
\hline Porphobilinogen synthase & 2.3 & 5-aminolevulinate dehydratase $=$ porphobilinogen synthase \\
\hline Fused predicted pyruvate-flavodoxin oxidoreductase & 2.3 & Putative oxidoreductase, Fe-S subunit \\
\hline Nitrite reductase, $\mathrm{NAD}(\mathrm{P}) \mathrm{H}$-binding, small subunit & 2.3 & Nitrite reductase \\
\hline Sorbitol-6-phosphate dehydrogenase & 2.3 & Glucitol \\
\hline $\begin{array}{l}\text { el } 4 \text { prophage; predicted DNA-binding transcriptional } \\
\text { regulator }\end{array}$ & 2.3 & orf, hypothetical protein \\
\hline Inhibitor of replication at Ter, DNA-binding protein & 2.2 & DNA-binding protein; inhibition of replication at Ter sites \\
\hline Glycerol-3-phosphate O-acyltransferase & 2.2 & Glycerol-3-phosphate acyltransferase \\
\hline Predicted DNA-binding transcriptional regulator & 2.2 & orf, hypothetical protein \\
\hline (D)-glucarate dehydratase I & 2.2 & Putative glucarate dehydratase \\
\hline Sodium:serine/threonine symporter & 2.2 & Putative transport protein \\
\hline Conserved protein & 2.2 & orf, hypothetical protein \\
\hline
\end{tabular}


Table S2 (Continued)

\begin{tabular}{|c|c|c|}
\hline Gene product & $\begin{array}{l}\text { Fold change } \\
\text { AgNP-ZM } \\
\text { vs zeolite }\end{array}$ & Description \\
\hline D-xylose transporter & 2.2 & Xylose-proton symport \\
\hline Sodium-proton antiporter & 2.2 & $\mathrm{Na}+/ \mathrm{H}$ antiporter, $\mathrm{pH}$ dependent \\
\hline Endonuclease IV with intrinsic 3'-5' exonuclease activity & 2.2 & Endonuclease IV \\
\hline Pseudo & 2.2 & Putative transport system permease protein \\
\hline Conserved protein & 2.2 & orf, hypothetical protein \\
\hline $\begin{array}{l}\text { KpLE2 phage-like element; IS2 insertion element } \\
\text { transposase InsAB' }\end{array}$ & 2.2 & IS2 hypothetical protein \\
\hline 4-alpha-glucanotransferase (amylomaltase) & 2.1 & 4-alpha-glucanotransferase \\
\hline $\begin{array}{l}\text { Predicted transporter subunit: periplasmic-binding } \\
\text { component of } A B C \text { superfamily }\end{array}$ & 2.1 & Putative transport periplasmic protein \\
\hline Predicted DNA-binding transcriptional regulator & 2.1 & Putative transcriptional regulator LYSR-type \\
\hline Conserved protein & 2.1 & orf, hypothetical protein \\
\hline Catalase/hydroperoxidase HPI(I) & 2.1 & Catalase; hydroperoxidase HPI \\
\hline Crotonobetaine reductase subunit II, FAD-binding & 2.1 & Probable carnitine operon oxidoreductase \\
\hline CP4-6 prophage; predicted ferric transporter subunit & 2.1 & Putative ATP-binding component of a transport system \\
\hline Exonuclease III & 2.1 & Exonuclease III \\
\hline Dihydroxyacid dehydratase & 2.1 & Dihydroxyacid dehydratase \\
\hline $\begin{array}{l}\text { Sn-glycerol-3-phosphate dehydrogenase, aerobic, } \\
\text { FAD/NAD(P)-binding }\end{array}$ & 2.1 & Sn-glycerol-3-phosphate dehydrogenase \\
\hline $\begin{array}{l}\text { Fused DNA-binding response regulator in two-component } \\
\text { regulatory system with Zra }\end{array}$ & 2.1 & Response regulator of hydrogenase 3 activity \\
\hline Nitrite reductase, $\mathrm{NAD}(\mathrm{P}) \mathrm{H}$-binding, small subunit & 2.1 & Nitrite reductase \\
\hline $\begin{array}{l}\text { 3-deoxy-D-arabino-heptulosonate-7-phosphate } \\
\text { synthase, tyrosine-repressible }\end{array}$ & 2.1 & 3-deoxy-D-arabinoheptulosonate-7-phosphate synthase \\
\hline Conserved inner membrane protein & 2.1 & orf, hypothetical protein \\
\hline DNA-binding protein, hemimethylated & 2 & orf, hypothetical protein \\
\hline Conserved protein & 2 & Putative receptor \\
\hline Conserved inner membrane protein & 2 & orf, hypothetical protein \\
\hline Dihydroxyacetone kinase, C-terminal domain & 2 & Putative dihydroxyacetone kinase \\
\hline $\begin{array}{l}\text { Predicted transporter subunit: ATP-binding component } \\
\text { of } A B C \text { superfamily }\end{array}$ & 2 & Putative ATP-binding component of a transport system \\
\hline
\end{tabular}

Table S3 Decreases in Escherichia coli gene expression in response to 30-minute exposures to four independent zeolite supports containing silver nanoparticles versus $E$. coli exposed to four independent zeolite controls

\begin{tabular}{|c|c|c|c|}
\hline $\begin{array}{l}\text { Gene } \\
\text { name }\end{array}$ & Gene product & $\begin{array}{l}\text { Fold change } \\
\text { AgNP-ZM vs } \\
\text { zeolite }\end{array}$ & Description \\
\hline fliQ & Flagellar biosynthesis protein & -2 & Flagellar biosynthesis \\
\hline$m d t Q$ & Pseudo & -2 & orf, hypothetical protein \\
\hline yhdE & Conserved protein & -2 & orf, hypothetical protein \\
\hline yciT & $\begin{array}{l}\text { Predicted DNA-binding transcriptional } \\
\text { regulator }\end{array}$ & -2 & Putative DEOR-type transcriptional regulator \\
\hline yjcC & $\begin{array}{l}\text { Predicted signal transduction protein } \\
\text { (EAL domain containing protein) }\end{array}$ & -2 & orf, hypothetical protein \\
\hline yehE & Predicted protein & -2 & orf, hypothetical protein \\
\hline sdiA & DNA-binding transcriptional activator & -2 & Transcriptional regulator of fts $\mathrm{QAZ}$ gene cluster \\
\hline yeeA & Conserved inner membrane protein & -2 & orf, hypothetical protein \\
\hline yncH & Predicted protein & -2 & orf, hypothetical protein \\
\hline$n d k$ & Multifunctional nucleoside diphosphate kinase & -2 & Nucleoside diphosphate kinase \\
\hline yebW & Predicted protein & -2 & orf, hypothetical protein \\
\hline ycjW & $\begin{array}{l}\text { Predicted DNA-binding transcriptional } \\
\text { regulator }\end{array}$ & -2 & Putative LACl-type transcriptional regulator \\
\hline
\end{tabular}


Table S3 (Continued)

\begin{tabular}{|c|c|c|c|}
\hline $\begin{array}{l}\text { Gene } \\
\text { name }\end{array}$ & Gene product & $\begin{array}{l}\text { Fold change } \\
\text { AgNP-ZM vs } \\
\text { zeolite }\end{array}$ & Description \\
\hline$y c g N$ & Conserved protein & -2.1 & orf, hypothetical protein \\
\hline als $A$ & $\begin{array}{l}\text { Fused D-allose transporter subunits of } A B C \\
\text { superfamily: ATP-binding components }\end{array}$ & -2.1 & Putative ATP-binding component of a transport system \\
\hline sugE & Multidrug efflux system protein & -2.1 & Suppresses groEL, may be chaperone \\
\hline$y b b D$ & pseudo & -2.1 & orf, hypothetical protein \\
\hline yjhl & $\begin{array}{l}\text { KpLE2 phage-like element; predicted DNA- } \\
\text { binding transcriptional regulator }\end{array}$ & -2.1 & Putative regulator \\
\hline$g / c F$ & Glycolate oxidase iron-sulfur subunit & -2.1 & Glycolate oxidase iron-sulfur subunit \\
\hline ybdO & $\begin{array}{l}\text { Predicted DNA-binding transcriptional } \\
\text { regulator }\end{array}$ & -2.1 & Putative transcriptional regulator LYSR-type \\
\hline mcrA & $\begin{array}{l}\text { el } 4 \text { prophage; } 5 \text {-methylcytosine-specific } \\
\text { restriction endonuclease } B\end{array}$ & -2.1 & $\begin{array}{l}\text { Restriction of DNA at 5-methylcytosine residues; at locus } \\
\text { of el } 4 \text { element }\end{array}$ \\
\hline efeB & Conserved protein & -2.1 & orf, hypothetical protein \\
\hline yabP & Pseudo & -2.1 & orf, hypothetical protein \\
\hline $\operatorname{arn} T$ & 4-amino-4-deoxy-L-arabinose transferase & -2.1 & orf, hypothetical protein \\
\hline ais & Conserved protein & -2.1 & Protein induced by aluminum \\
\hline$r s \times C$ & $\begin{array}{l}\text { Fused predicted } 4 \mathrm{Fe}-4 \mathrm{~S} \text { ferredoxin-type } \\
\text { protein/conserved protein }\end{array}$ & -2.1 & Putative membrane protein \\
\hline yagU & Conserved inner membrane protein & -2.1 & orf, hypothetical protein \\
\hline yciF & Conserved protein & -2.1 & Putative structural proteins \\
\hline yifK & Predicted transporter & -2.1 & Putative amino acid/amine transport protein \\
\hline yncD & Predicted iron outer membrane transporter & -2.1 & Putative outer membrane receptor for iron transport \\
\hline yhcO & Predicted barnase inhibitor & -2.1 & orf, hypothetical protein \\
\hline elaD & Predicted enzyme & -2.1 & Putative sulfatase/phosphatase \\
\hline eamA & Cysteine and O-acetyl-L-serine efflux system & -2.1 & orf, hypothetical protein \\
\hline$g l c D$ & Glycolate oxidase subunit, FAD-linked & -2.1 & Glycolate oxidase subunit D \\
\hline$y d g C$ & $\begin{array}{l}\text { Conserved inner membrane protein associated } \\
\text { with alginate biosynthesis }\end{array}$ & -2.2 & orf, hypothetical protein \\
\hline sugE & Multidrug efflux system protein & -2.2 & Suppresses groEL, may be chaperone \\
\hline alsC & D-allose transporter subunit & -2.2 & Putative transport system permease protein \\
\hline yifK & Predicted transporter & -2.2 & Putative amino acid/amine transport protein \\
\hline yhhY & Predicted acetyltransferase & -2.2 & orf, hypothetical protein \\
\hline fhuB & $\begin{array}{l}\text { Fused iron-hydroxamate transporter subunits } \\
\text { of } A B C \text { superfamily: membrane components }\end{array}$ & -2.2 & $\begin{array}{l}\text { Hydroxamate-dependent iron uptake, cytoplasmic membrane } \\
\text { component }\end{array}$ \\
\hline hdeB & Acid-resistance protein & -2.2 & orf, hypothetical protein \\
\hline yfhA & $\begin{array}{l}\text { Predicted DNA-binding response regulator } \\
\text { in two-component system }\end{array}$ & -2.2 & Putative 2-component transcriptional regulator \\
\hline glgS & Predicted glycogen synthesis protein & -2.2 & Glycogen biosynthesis, rpoS dependent \\
\hline ydaQ & Rac prophage; conserved protein & -2.2 & orf, hypothetical protein \\
\hline ylbH & Pseudo & -2.2 & orf, hypothetical protein \\
\hline rfaP & $\begin{array}{l}\text { Kinase that phosphorylates core heptose } \\
\text { of lipopolysaccharide }\end{array}$ & -2.2 & $\begin{array}{l}\text { Lipopolysaccharide core biosynthesis; phosphorylation of } \\
\text { core heptose }\end{array}$ \\
\hline $\operatorname{stp} A$ & DNA binding protein, nucleoid-associated & -2.2 & DNA-binding protein; H-NS-like protein; chaperone activity \\
\hline IpxT & Undecaprenyl pyrophosphate phosphatase & -2.2 & orf, hypothetical protein \\
\hline ydhY & Predicted 4Fe-4S ferridoxin-type protein & -2.2 & Putative oxidoreductase, Fe-S subunit \\
\hline yifK & Predicted transporter & -2.2 & Putative amino acid/amine transport protein \\
\hline his $P$ & $\begin{array}{l}\text { Histidine/lysine/arginine/ornithine transporter } \\
\text { subunit }\end{array}$ & -2.2 & ATP-binding component of histidine transport \\
\hline yhgE & Predicted inner membrane protein & -2.2 & Putative transport \\
\hline thiQ & Thiamin transporter subunit & -2.2 & Putative ATP-binding component of a transport system \\
\hline$y c g Z$ & Predicted protein & -2.2 & orf, hypothetical protein \\
\hline glcG & Conserved protein & -2.2 & orf, hypothetical protein \\
\hline
\end{tabular}


Table S3 (Continued)

\begin{tabular}{|c|c|c|c|}
\hline $\begin{array}{l}\text { Gene } \\
\text { name }\end{array}$ & Gene product & $\begin{array}{l}\text { Fold change } \\
\text { AgNP-ZM vs } \\
\text { zeolite }\end{array}$ & Description \\
\hline flip & Flagellar biosynthesis protein & -2.2 & Flagellar biosynthesis \\
\hline yibF & Predicted glutathione S-transferase & -2.2 & Putative S-transferase \\
\hline rpiR & DNA-binding transcriptional repressor & -2.4 & Transcriptional repressor of rpiB expression \\
\hline yojl & $\begin{array}{l}\text { Fused predicted multidrug transport subunits } \\
\text { of } A B C \text { superfamily }\end{array}$ & -2.4 & Putative ATP-binding component of a transport system \\
\hline hsdS & Specificity determinant for hsdM and hsdR & -2.4 & Specificity determinant for hsdM and hsdR \\
\hline $\operatorname{rac} R$ & $\begin{array}{l}\text { Rac prophage; predicted DNA-binding } \\
\text { transcriptional regulator }\end{array}$ & -2.4 & orf, hypothetical protein \\
\hline ycel & Predicted protein & -2.4 & orf, hypothetical protein \\
\hline $\operatorname{ton} B$ & $\begin{array}{l}\text { Membrane spanning protein in TonB-ExbB- } \\
\text { ExbD complex }\end{array}$ & -2.4 & $\begin{array}{l}\text { Energy transducer; uptake of iron, cyanocobalimin; sensitivity } \\
\text { to phages }\end{array}$ \\
\hline rfas & Lipopolysaccharide core biosynthesis protein & -2.5 & Lipopolysaccharide core biosynthesis \\
\hline rutB & Predicted enzyme & -2.5 & Putative synthetase \\
\hline ycil & Predicted enzyme & -2.5 & orf, hypothetical protein \\
\hline$w z y E$ & $\begin{array}{l}\text { Predicted Wzy protein involved in ECA } \\
\text { polysaccharide chain elongation }\end{array}$ & -2.5 & $\begin{array}{l}\text { TDP-Fuc } 4 \mathrm{NAc} \text { :lipidll transferase; synthesis of enterobacterial } \\
\text { common Ag }\end{array}$ \\
\hline nth & $\begin{array}{l}\text { DNA glycosylase and apyrimidinic (AP) } \\
\text { lyase (endonuclease III) }\end{array}$ & -2.5 & Endonuclease III; specific for apurinic and/or apyrimidinic sites \\
\hline yncC & $\begin{array}{l}\text { Predicted DNA-binding transcriptional } \\
\text { regulator }\end{array}$ & -2.5 & orf, hypothetical protein \\
\hline yifK & Predicted transporter & -2.5 & Putative amino acid/amine transport protein \\
\hline yjhB & $\begin{array}{l}\text { KpLE2 phage-like element; predicted } \\
\text { transporter }\end{array}$ & -2.5 & Putative transport protein \\
\hline yhjR & Conserved protein & -2.5 & orf, hypothetical protein \\
\hline yfdl & $\begin{array}{l}\text { CPS-53 (KpLEI) prophage; predicted inner } \\
\text { membrane protein }\end{array}$ & -2.5 & putative ligase \\
\hline yifN & pseudo & -2.6 & orf, hypothetical protein \\
\hline caiF & DNA-binding transcriptional activator & -2.6 & Transcriptional regulator of cai operon \\
\hline$f \lg A$ & $\begin{array}{l}\text { assembly protein for flagellar basal-body } \\
\text { periplasmic } P \text { ring }\end{array}$ & -2.6 & $\begin{array}{l}\text { Flagellar biosynthesis; assembly of basal-body periplasmic } \mathrm{P} \\
\text { ring }\end{array}$ \\
\hline $\operatorname{ser} A$ & D-3-phosphoglycerate dehydrogenase & -2.6 & D-3-phosphoglycerate dehydrogenase \\
\hline can & Carbonic anhydrase & -2.7 & Putative carbonic anhdrase \\
\hline yacC & Predicted protein & -2.7 & orf, hypothetical protein \\
\hline$y d b L$ & Conserved protein & -2.7 & orf, hypothetical protein \\
\hline $\mathrm{efeO}$ & Conserved protein & -2.7 & orf, hypothetical protein \\
\hline fliF & Flagellar basal-body MS-ring and collar protein & -2.7 & Flagellar biosynthesis; basal-body MS \\
\hline flgC & $\begin{array}{l}\text { Flagellar component of cell-proximal portion } \\
\text { of basal-body rod }\end{array}$ & -2.7 & Flagellar biosynthesis, cell-proximal portion of basal-body rod \\
\hline can & Carbonic anhydrase & -2.7 & Putative carbonic anhdrase \\
\hline$r s x D$ & Predicted inner membrane oxidoreductase & -2.7 & orf, hypothetical protein \\
\hline fliM & $\begin{array}{l}\text { Flagellar motor switching and energizing } \\
\text { component }\end{array}$ & -2.7 & $\begin{array}{l}\text { Flagellar biosynthesis, component of motor switch and } \\
\text { energizing }\end{array}$ \\
\hline$y b a N$ & Conserved inner membrane protein & -2.8 & Putative gene 58 \\
\hline proV & Glycine betaine transporter subunit & -2.8 & $\begin{array}{l}\text { ATP-binding component of transport system for glycine, } \\
\text { betaine and proline }\end{array}$ \\
\hline fhuD & Iron-hydroxamate transporter subunit & -2.8 & $\begin{array}{l}\text { Hydroxamate-dependent iron uptake, cytoplasmic membrane } \\
\text { component }\end{array}$ \\
\hline can & Carbonic anhydrase & -2.8 & Putative carbonic anhdrase \\
\hline sufE & Sulfur acceptor protein & -2.8 & orf, hypothetical protein \\
\hline sufs & Selenocysteine lyase, PLP-dependent & -2.8 & orf, hypothetical protein \\
\hline $\operatorname{ariR}$ & Predicted protein & -2.8 & orf, hypothetical protein \\
\hline wcaM & Predicted colanic acid biosynthesis protein & -2.8 & orf, hypothetical protein \\
\hline ymgA & Predicted protein & -2.9 & orf, hypothetical protein \\
\hline
\end{tabular}


Table S3 (Continued)

\begin{tabular}{|c|c|c|c|}
\hline $\begin{array}{l}\text { Gene } \\
\text { name }\end{array}$ & Gene product & $\begin{array}{l}\text { Fold change } \\
\text { AgNP-ZM vs } \\
\text { zeolite }\end{array}$ & Description \\
\hline ybiX & Conserved protein & -2.9 & Putative enzyme \\
\hline yacC & Predicted protein & -2.9 & orf, hypothetical protein \\
\hline sufC & $\begin{array}{l}\text { Component of SufBCD complex, ATP-binding } \\
\text { component of } A B C \text { superfamily }\end{array}$ & -2.9 & Putative ATP-binding component of a transport system \\
\hline can & Carbonic anhydrase & -2.9 & Putative carbonic anhydrase \\
\hline yacC & Predicted protein & -3 & orf, hypothetical protein \\
\hline fhuC & Iron-hydroxamate transporter subunit & -3 & $\begin{array}{l}\text { ATP-binding component of hydroxymate-dependent iron } \\
\text { transport }\end{array}$ \\
\hline $\operatorname{sod} A$ & Superoxide dismutase, $M n$ & -3.1 & Superoxide dismutase, manganese \\
\hline can & Carbonic anhydrase & -3.2 & Putative carbonic anhydrase \\
\hline$c b r B$ & Predicted inner membrane protein & -3.2 & orf, hypothetical protein \\
\hline$f \lg B$ & $\begin{array}{l}\text { Flagellar component of cell-proximal portion } \\
\text { of basal-body rod }\end{array}$ & -3.3 & Flagellar biosynthesis, cell-proximal portion of basal-body rod \\
\hline ompT & $\begin{array}{l}\text { DLPI } 2 \text { prophage; outer membrane protease } \\
\text { VII (outer membrane protein } 3 b \text { ) }\end{array}$ & -3.3 & Outer membrane protein $3 b$ \\
\hline$r s x E$ & $\begin{array}{l}\text { Predicted inner membrane NADH-quinone } \\
\text { reductase }\end{array}$ & -3.3 & orf, hypothetical protein \\
\hline pqqL & Predicted peptidase & -3.3 & Putative peptidase \\
\hline fliA & RNA polymerase, sigma 28 (sigma F) factor & -3.3 & Flagellar biosynthesis; alternative sigma factor 28 \\
\hline yfdH & $\begin{array}{l}\text { CPS-53 (KpLEI) prophage; bactoprenol } \\
\text { glucosyl transferase }\end{array}$ & -3.5 & Putative glycan biosynthesis enzyme \\
\hline yjgL & Predicted protein & -3.5 & orf, hypothetical protein \\
\hline sufD & Component of SufBCD complex & -3.7 & orf, hypothetical protein \\
\hline$y f d H$ & $\begin{array}{l}\text { CPS-53 (KpLEI) prophage; bactoprenol } \\
\text { glucosyl transferase }\end{array}$ & -3.7 & Putative glycan biosynthesis enzyme \\
\hline fepB & Iron-enterobactin transporter subunit & -3.7 & Ferric enterobactin \\
\hline fliL & Flagellar biosynthesis protein & -3.7 & Flagellar biosynthesis \\
\hline sufB & Component of SufBCD complex & -3.7 & orf, hypothetical protein \\
\hline sufA & Fe-S cluster assembly protein & -3.8 & orf, hypothetical protein \\
\hline ycgF & Predicted FAD-binding phosphodiesterase & -3.8 & orf, hypothetical protein \\
\hline yfdH & $\begin{array}{l}\text { CPS-53 (KpLEI) prophage; bactoprenol } \\
\text { glucosyl transferase }\end{array}$ & -3.8 & Putative glycan biosynthesis enzyme \\
\hline sufA & Fe-S cluster assembly protein & -3.9 & orf, hypothetical protein \\
\hline$y b d B$ & Conserved protein & -4 & orf, hypothetical protein \\
\hline fhuE & $\begin{array}{l}\text { Ferric-rhodotorulic acid outer membrane } \\
\text { transporter }\end{array}$ & -4 & Outer membrane receptor for ferric iron uptake \\
\hline sufA & Fe-S cluster assembly protein & -4.3 & orf, hypothetical protein \\
\hline$y f d H$ & $\begin{array}{l}\text { CPS-53 (KpLEI) prophage; bactoprenol } \\
\text { glucosyl transferase }\end{array}$ & -4.4 & Putative glycan biosynthesis enzyme \\
\hline $\operatorname{exbD}$ & $\begin{array}{l}\text { Membrane spanning protein in TonB-ExbB- } \\
\text { ExbD complex }\end{array}$ & -4.5 & Uptake of enterochelin; tonB-dependent uptake of B colicins \\
\hline yncE & Conserved protein & -4.5 & Putative receptor \\
\hline fepD & Iron-enterobactin transporter subunit & -4.7 & Ferric enterobactin \\
\hline sufA & Fe-S cluster assembly protein & -4.9 & orf, hypothetical protein \\
\hline entB & Isochorismatase & -5 & $\begin{array}{l}\text { 2,3-dihydro-2,3-dihydroxybenzoate synthetase, } \\
\text { isochroismatase }\end{array}$ \\
\hline entC & Isochorismate synthase I & -5.3 & Isochorismate hydroxymutase 2 , enterochelin biosynthesis \\
\hline$t d c A$ & DNA-binding transcriptional activator & -5.3 & Transcriptional activator of tdc operon \\
\hline fepA & Iron-enterobactin outer membrane transporter & -5.4 & Outer membrane receptor for ferric enterobactin \\
\hline fepC & Iron-enterobactin transporter subunit & -5.6 & ATP-binding component of ferric enterobactin transport \\
\hline fes & Enterobactin/ferric enterobactin esterase & -5.6 & Enterochelin esterase \\
\hline $\operatorname{exbB}$ & $\begin{array}{l}\text { Membrane spanning protein in TonB-ExbB- } \\
\text { ExbD complex }\end{array}$ & -5.8 & Uptake of enterochelin; tonB-dependent uptake of B colicins \\
\hline
\end{tabular}


Table S3 (Continued)

\begin{tabular}{|c|c|c|c|}
\hline $\begin{array}{l}\text { Gene } \\
\text { name }\end{array}$ & Gene product & $\begin{array}{l}\text { Fold change } \\
\text { AgNP-ZM vs } \\
\text { zeolite }\end{array}$ & Description \\
\hline$n r d H$ & Glutaredoxin-like protein & -5.8 & Glutaredoxin-like protein; hydrogen donor \\
\hline$f e c R$ & $\begin{array}{l}\text { KpLE2 phage-like element; transmembrane } \\
\text { signal transducer for ferric citrate transport }\end{array}$ & -5.9 & Regulator for fec operon, periplasmic \\
\hline entS & Predicted transporter & -6.6 & Putative transport \\
\hline entF & $\begin{array}{l}\text { Enterobactin synthase multienzyme complex } \\
\text { component, ATP-dependent }\end{array}$ & -6.8 & ATP-dependent serine activating enzyme \\
\hline cirA & $\begin{array}{l}\text { Ferric iron-catecholate outer membrane } \\
\text { transporter }\end{array}$ & -7.1 & $\begin{array}{l}\text { Outer membrane receptor for iron-regulated colicin I } \\
\text { receptor; porin }\end{array}$ \\
\hline entA & $\begin{array}{l}\text { 2,3-dihydro-2,3-dihydroxybenzoate } \\
\text { dehydrogenase }\end{array}$ & -7.2 & 2,3-dihydro-2,3-dihydroxybenzoate dehydrogenase \\
\hline entE & $\begin{array}{l}\text { 2,3-dihydroxybenzoate-AMP ligase component } \\
\text { of enterobactin synthase multienzyme complex }\end{array}$ & -7.4 & 2,3-dihydroxybenzoate-AMP ligase \\
\hline$y d d B$ & Predicted porin protein & -7.9 & orf, hypothetical protein \\
\hline fecl & $\begin{array}{l}\text { KpLE2 phage-like element; RNA polymerase, } \\
\text { sigma } 19 \text { factor }\end{array}$ & -8.5 & Probable RNA polymerase sigma factor \\
\hline nrdl & Protein that stimulates ribonucleotide reduction & -8.8 & orf, hypothetical protein \\
\hline ydiE & Conserved protein & -9.2 & orf, hypothetical protein \\
\hline$n r d E$ & $\begin{array}{l}\text { Ribonucleoside-diphosphate reductase } 2 \text {, } \\
\text { alpha subunit }\end{array}$ & -10.4 & Ribonucleoside-diphosphate reductase 2 , alpha subunit \\
\hline$b f d$ & Bacterioferritin-associated ferredoxin & -10.6 & orf, hypothetical protein \\
\hline$y d d A$ & $\begin{array}{l}\text { Fused predicted multidrug transporter } \\
\text { subunits of } A B C \text { superfamily }\end{array}$ & -12.4 & Putative ATP-binding component of a transport system \\
\hline fepG & Iron-enterobactin transporter subunit & -12.6 & Ferric enterobactin transport protein \\
\hline fiu & Predicted iron outer membrane transporter & -13.7 & Putative outer membrane receptor for iron transport \\
\hline$n r d F$ & $\begin{array}{l}\text { Ribonucleoside-diphosphate reductase } 2 \text {, beta } \\
\text { subunit, ferritin-like protein }\end{array}$ & -13.9 & Ribonucleoside-diphosphate reductase 2 , beta chain, frag \\
\hline fhuF & $\begin{array}{l}\text { Ferric iron reductase involved in ferric } \\
\text { hydroximate transport }\end{array}$ & -17.6 & orf, hypothetical protein \\
\hline
\end{tabular}

\section{Supplemental References}

1. Gentleman RC, Carey VJ, Bates DM et al. Bioconductor: Open software development for computational biology and bioinformatics. Genome Biol. 2004;5(10):R80.

2. Tusher VG, Tibshirani R, Chu G. Significance analysis of microarrays applied to the ionizing radiation response. Proc Natl Acad Sci U S A. 2001;98(9):5116-5121.
3. Storey JD, Tibshirani, R. Statistical significance for genomewide studies. Proc Natl Acad Sci U S A. 2003;100(16):9440-9445.
International Journal of Nanomedicine

\section{Publish your work in this journal}

The International Journal of Nanomedicine is an international, peerreviewed journal focusing on the application of nanotechnology in diagnostics, therapeutics, and drug delivery systems throughout the biomedical field. This journal is indexed on PubMed Central, MedLine, CAS, SciSearch ${ }^{\circledR}$, Current Contents ${ }^{\circledR} /$ Clinical Medicine,

\author{
Proc Natl Acad Sci U SA. 2003,100(16):9440-9445.
}

